This article is distributed under the terms of the Creative Commons Attribution 3.0 PL (c) Copyright by Uniwersytet Warszawski Katedra Studiów Interkulturowych Europy Środkowo-Wschodniej \& individual articles to their Authors

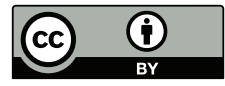

doi: 10.32612/uw.2543618X.2020.pp.127-167

Przegląd Środkowo-Wschodni, 5, 2020

ISSN 2543-618X elSSN 2545-1324

Nr art. 20200504

Data przesłania: 09.08.2019

Data akceptacji: 12.10.2019

Віктар Корбут

Uniwersytet Warszawski

v.korbut@uw.edu.pl

ORCiD: 0000-0001-6848-1160

\title{
Ідэнтычнасць жыхароў Мінска ў XIX - пачатку XX ст. у святле мемуарнай літаратуры
}

\section{Tożsamość mieszkańców Mińska w XIX - na początku XX w. w świetle piśmiennictwa pamiętnikarskiego}

Wspomnienia mieszkańców Mińska są bardzo cennym źródłem do zrozumienia historii miasta. Ich szczególną wartością jest to, że pokazują życie miasta od wewnątrz, ze wszystkimi sprzecznościami. Mieszkańcy Mińska, którzy uważali się za Polaków, stanowili bardzo znaczną część jego mieszkańców do 1863 r.Wpłynęli na życie miasta, utrzymali te pozycję, choć w mniejszym stopniu do 1917 r.W XIX i na początku XX W., pomimo tego że miasto było częścią Imperium Rosyjskiego, Mińsk, podobnie jak w poprzednim okresie, kiedy był częścią Wielkiego Księstwa Litewskiego i Rzeczypospolitej Obojga Narodów, był częścią polskojęzycznej przestrzeni kulturowej i mentalnej. Wśród mieszkańców miasta, głównie wiary katolickiej, ale także grecko-katolickiej (po 1839 r. - wśród prawosławnych, byłych unitów), szlachty i mieszczan, językiem kultury i codziennej komunikacji był polski, ale jednocześnie przywiązywano do tradycji dawnej Rzeczypospolitej Obojga Narodów. Jednocześnie Mińsk lub Mińsk Litewski był rozumiany jako miasto na Litwie - tj. na terytorium byłego Wielkiego Księstwa Litewskiego i Rzeczypospolitej Obojga Narodów. W tym artykule, na podstawie wspomnień ówczesnych mieszkańców i gości miasta - Tadeusza Korzona, Zofii Kowalewskiej, Ferdynanda Szabłowskiego, Ferdynanda Ruszczyca, Jana Bułhaka, Adama Bohdanowicza, Anieli Bohdanowiczowej, Mikałaja Ułaszczyka i in. - podjęto próbę odzwierciedlenia ich postrzegania Mińska i miejsca miasta na ówczesnej Litwie i Białorusi, w Polsce i Rosji. 
Słowa kluczowe: Mińsk, pamiętnikarstwo, Polacy, Białorusini, Żydzi, Rosjanie, powstanie styczniowe

Мо’а і Мінск наш цяпер не такі, Як, дзеткі, калісьці, у прошлы вякі? [...] Да што й памінаць.... - Мінск кіпеў вясёлы! Паночкі гулялі! - баш ясны саколы!

Вінцэнт Дунін-Марцінкевіч (Wincenty Dunin-Marcinkiewicz), «Вечарніцы» $(1855 \text { г. })^{1}$

A ziemia ta - to ziemia od wieków użyźniona kulturą naszą.

Фердыданд Рушчыц (Ferdynand Ruszczyc)

$(1911 \text { г. })^{2}$

Мемуары і дзённікі з'яўляюцца каштоўнай крыніцай па гісторыі Беларусі, што адзначаў яшчэ вядомы беларускі і расійскі археограф Мікалай Улашчык: «напісаныя часта праз шмат гадоў пасля апісаных падзей, яны не могуць вылучацца дакладнасцю», аднак «разам 3 тым яны даюць тое, чаго нестае афіцыйным крыніцам: даносяць атмасферу свайго часу, паведамляюць дэталі, якія нельга знайсці ні ў якіх афіцыйных і неафіцыйных дакументах»³.

У XIX - пачатку XX ст., нягледзячы на знаходжанне ў складзе Расійскай імперыі, Мінск, як і ў папярэдні перыяд, калі ўваходзіў у склад Вялікага Княства Літоўскага і Рэчы Паспалітай, з'яўляўся часткай польскамоўнай культурнай, ментальнай прасторы. Сярод жыхароў горада, пераважна каталіцкага веравызнання, але таксама

${ }^{1}$ В. Дунін-Марцінкевіч, Збор твораў. У 2 m. T. 1. Драматычныя творы, вершаваныя аповесці і апавяданні, укл. Я. Янушкевіч, Мінск 2007, с. 422.

${ }^{2}$ o-K-o, Mińsk. Dwa światy, «Tygodnik Wileński» 1911, nr 13, 27 marca (9 kwietnia), s. 3 .

${ }^{3}$ М. Улашчык, Мемуары $і$ дзённікі як крыніцы па гісторыі Беларусі [у:] Idem, Збор творай. Т. 1. Працы па археаграфіi і крыніцазнаўству, рэд. Д. Віцько, Д. Столяр, М. Гальпяровіч, агульн. рэд. Д. Віцько, Смоленск 2017, с. 1145. 
Віктар Корбут, Ідэнтычнасць жыхароў Мінска ў XIX - пачатку XX ст... 129

і грэка-каталіцкага (пасля 1839 г. - сярод часткі праваслаўных, былых уніятаў), шляхты і мяшчан мовай культуры і штодзённых зносін з'яўлялася польская, разам з тым існавала прывязанасць да традыцый былой Рэчы Паспалітай Абодвух Народаў - Польшчы i Літвы. Пры гэтым Мінск (Mińsk), або Мінск-Літоўскі (Mińsk Litewski) разумеўся як горад у Літве («w Litwie», «na Litwie») - г. зн. на тэрыторыі былога Вялікага Княства Літоўскага, часткі колішняй Рэчы Паспалітай.

Паводле даных, апублікаваных у 1857 г. Уладзіславам Сыракомлем, у Мінску ў той час католікі складалі другую па колькасці групу насельніцтва - 4215 мужчын і 3196 жанчын, праваслаўных налічвалася 1868 мужчын і 1679 жанчын, яўрэяў - 7200 мужчын і 6673 жанчыны, мусульман - 150 мужчын і 133 жанчыны, лютэран

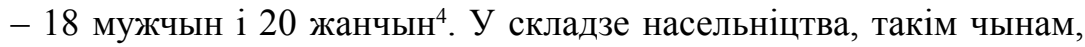
дамінавалі католікі і іўдзеі.

У гэтым артыкуле на падставе мемуараў тагачасных жыхароў горада зроблена спроба адлюстраваць іх успрыманне Мінска і ўвогуле таго краю, у якім яны жылі. Сярод успамінау вылучаюцца запісы Тадэвуша Корзана (Tadeusz Korzon), ураджэнца Мінска, вядомага польскага гісторыка5, і Зоф’і Кавалеўскай (Zofia Kowalewska)'. Выдадзеныя ў адзін час - у 1912 г. (Т. Корзан скончыў пісаць іх у 1906 г.), яны адлюстроўваюць настрой таго пакалення, якое яшчэ заспела «польскі» Мінск-Літоўскі - да 1863 г., калі ў выніку задушэння Студзеньскага паўстання і ў рамках палітыкі ўзмоцненай русіфікацыі пачалося планамернае закрыццё польскіх культурных і грамадскіх устаноў, ліквідацыя прысутнасці польскай мовы і культуры ў публічнай прасторы горада «ў Літве». Варта дадаць,

${ }^{4}$ Мінск у апісанні Уладзіслава Сыракомлі [у:] Памяць: гісторыка-дакументальная хроніка Мінска. У 4 кн. Кн. 1, Мінск 2001, с. 388.

${ }^{5}$ T. Korzon, Mój pamiętnik przedhistoryczny, Kraków 1912; Корзан Т., Мінск у сярэдзіне XIX cm. 3 уласных успамінаў, пер. В. Макарэвіч, «Arche» 2010, № 3, c. $115-156$.

${ }^{6}$ Z. Kowalewska, Obrazki mińskie. 1850-1863, Wilno 1912. 
што 3. Кавалеўская ведала пра тое, што Т. Корзан жыў у Мінску: «Mieszkała też podówczas w Mińsku i rodzina znanego historyka Tadeusza Korzona» ${ }^{7},-$ але асабіста яны, праўдападобна, не былі знаёмы, бо ў той час, яшчэ з 1869 г., Т. Корзан жыў у Варшаве.

Ва ўспамінах, якія цытуюцца і аналізуюцца ў гэтым артыкуле, многа асабістага, суб'ектыўнага, як у любых такога роду творах, але адначасова аўтары робяць назіранні і абагульненні, якія ўносяць важныя акцэнты ва ўспрыманне Мінска XIX - пачатку XX ст. Таксама варта адзначыць, што 3. Кавалеўская не была відавочцам усіх падзей, якія апісвала. Як яна піша ва ўступе да сваёй кнігі, «materjału do «Obrazków» dostarczyły mi pamiętniki, rodzaj domowego Silva-Rerum, Ferdynanda Szabłowskiego, ówczesnego nauczyciela gimnazjum, oraz urzędowe dane, zaczerpnięte $\mathrm{z}$ archiwów szkolnych, notaty i wspomnienia rodzinne i opowiadania tych, co wówczas żyli, udział w wypadkach brali i pomimo sędziwego wieku, zdołali je świeżo przechować $\mathrm{w}$ ратіе̨сі» ${ }^{8}$. Такім чынам, спасылаючыся на 3. Кавалеўскую, мы павінны мець на ўвазе, што яе «сведчанні»гэта ў значнай меры пераказы ўспамінаў іншых асоб.

Асобае месца ў культурным жыцці Мінска 1850-х гг. адыграў пісьменнік Вінцэнт Дунін-Марцінкевіч, які пісаў на польскай і беларускай мовах і разам з кампазітарам Станіславам Манюшкам арганізоўваў паказы сваіх твораў на мінскай тэатральнай сцэне, на якой дзякуючы яму бадай упершыню прагучала беларуская мова.

Каштоўным сведчаннем пра Мінск 1860-х гг. з'яўляюцца ўспаміны педагога, этнографа Адама Багдановіча, бацькі беларускага паэта Максіма Багдановіча. Варта адзначыць, што яго асабістая гісторыя вельмі паказальная для адлюстравання той атмасферы, якая панавала ў Беларусі пасля 1863 г. А. Багдановіч стаў «ахвярай» таго сацыяльна-культурнага эксперымента, які праводзілі тут расійскія ўлады, змагаючыся з уплывамі польскай

\footnotetext{
${ }^{7}$ Ibidem, s. 36 .

${ }^{8}$ Ibidem, s. 3
} 
Віктар Корбут, Ідэнтычнасць жыхароў Мінска ў XIX - пачатку XX ст.... 131

культуры. У пасведчанні аб нараджэнні і хрышчэнні, выдадзеным А. Багдановічу Мінскай духоўнай кансісторыяй у 1896 г., Адольф Багдановіч, як ён быў названы пры нараджэнні, стаў Адамам, яго бацька Юры - «Георгием», а маці Анеля - «Анной»9 .

А. Багдановіч пакінуў яркае сведчанне таго, як ідэнтычнасць тутэйшых людзей сутыкалася 3 інтэрпрэтацыямі расійскіх чыноўнікаў, царкоўных іерархаў, якія масава пачалі прыбываць у краіну пасля 1863 г. У канцы 1860-х гг. А. Багдановіч сустракаўся 3 мінскім архірэем Аляксандрам Дабрыніным. Гэта быў «один из первых пришедших на смену старым униатским архиереям, т. е. один из обрусителей» ${ }^{10}$ : «Когда, благословившись, я, смущенный, стоял и не знал, что дальше делать, архиерей спросил: «Как тебя зовут?» - «Адольф».

- Как, как? - Я повторил. - А-a! - заметил он, - ты православный? - Я знал, что я православный, и сказал это. [...]

Потом я понял, почему он переспросил, как меня зовут: имя-то не православное» ${ }^{11}$.

Палітыка, якую праводзілі расійскія ўлады пасля 1863 г., была накіравана на аслабленне «ў Літве», у т. л. і ў Беларусі, «польскага элемента», аднак гэта мела негатыўныя наступствы і для беларускага і літоўскага «элемента».

Якім Мінск стаў у пачатку XX ст. дазваляюць уявіць успаміны мастака Фердынанда Рушчыца і яго калегі фатографа Яна Булгака (Jan Bułhak).

Для адлюстравання некаторых важных аспектаў ідэнтычнасці жыхароў Мінска, а таксама яго ваколіц выкарыстаны таксама іншыя мемуарныя крыніцы (напрыклад, Міхаіла Мураўёва, Мікалая Улашчыка) і гістарычная літаратура.

${ }^{9}$ А. Е. Богданович, Я всю жсизнь стремился к свету. В 2 кн. Кн. 1. Мои воспоминания, сост. А. Ващенко, Минск 2012, с. 5.

${ }^{10}$ Ibidem, c. 375 .

${ }^{11}$ Ibidem, c. 378. 
«Mińsk, jak wiele innych miast na Litwie»

Старонняму назіральніку Мінск у першай палове XIX ст. здаваўся польскім горадам. Расійскі падарожнік А. Башняк у кнізе «Дневные записки путешествия в разные области Западной и Полуденной России» так апісваў выгляд горада ў 1815 г.: «В середине же города все строение каменное и большей частью в готическом вкусе; так что можно не без оснований сказать, что снаружи Минск похож на русский, а в центре - на польский город. В различных местах возвышаются огромные костелы» ${ }^{12}$.

Аднак паступова польскія рысы з аблічча горада сціраліся. У 1830 г. былі «отмънены польскія названія присутственныхъ мъсть и должностей» ${ }^{13}$, у 1832 г. «skasowano język polski we wszystkich instytucjach rządowych i miejskich, zastępując go przez rosyjski» ${ }^{14}$. Самы моцны ўдар па пазіцыях польскай культуры ў Мінску быў нанесены ў 1863 г., а затым - наступствамі сацыяльнай рэвалюцы 1917 г. у Расійскай імперыі, у склад якой уваходзіў горад. Бо польская культура ў Мінску трымалася на пэўнай сацыяльнай групе - мясцовай шляхце.

Расказваючы пра падзеі 1812 г. у Мінску, 3. Кавалеўская піша: «Mińsk, jak wiele innych miast na Litwie» ${ }^{15}$. Увогуле, i Мінск, і Міншчына бачыліся 3. Кавалеўскай як частка Літвы. Гэта відаць, напрыклад, з яе расказу пра павятовага маршалка шляхты Ігнацы Багдашэўскага з Вязыня: «Bogdaszewski był też pierwszym i jedynym w Mińszczyźnie, a może i na Litwie, płatnym marszałkiem» ${ }^{16}$.

${ }^{12}$ В. А. Корбут, Ад Мінска да Вільні. Гісторыя Беларусі ў журналісикіх нататках, Мінск 2016, с. 249.

${ }^{13}$ Россія. Полное географическое описаніе нашего отечества: настольная и дорожная книга для русскихъ людей, ред. В. П. Семеновъ, общ. рук. П. П. Семенова и В. И. Ламанского. Т. IX. Верхнее Подньпровье и Бълоруссія, сост. В. П. Семеновъ, М. В. Довнаръ-Запольскій, Д. З. Шендрикъ, А. К. Кабановъ, А. П. Сапуновъ, С.-Петербургъ 1905, с. 418.

${ }^{14}$ Nasze Kościoły. Djecezja Mińska. T. 2. Zesz. 9, red. J. Żyskar, Warszawa 1913, s. 10 .

${ }^{15}$ Z. Kowalewska, op. cit., s. 11.

${ }^{16}$ Ibidem, s. 28. 
Віктар Корбут, Ідэнтычнасць жыхароў Мінска ў XIX - пачатку XX ст... 133

Калі паспрабаваць вызначыць, што было для 3. Кавалеўскай і прадстаўнікоў яе сацыяльнай групы (мясцовай польскамоўнай арыстакратыі) бацькаўшчынай, то можна паспрабаваць дапусціць існаванне шматузроўневай свядомасці: Мінск - Літва - Польшча. Трэба вельмі асцярожна, аднак, аперыраваць тэрмінамі «літоўскі», «польскі». Яны не супадаюць 3 сучаснымі значэннямі. Напрыклад, «родным заканадаўствам» Т. Корзан называе Статут Вялікага Княства Літоўскага, калі гаворыць, як «przygotowany był ukaz o zniesieniu Statutu Litewskiego czyli o zastąpieniu znakomitego, przez lat 400 wykonywanego, rodzimego prawodawstwa rosyjskim «Zwodem Praw» ${ }^{17}$. Улічваючы, што Т. Корзан нарадзіўся ў 1839 г., а дзеянне Статута ВКЛ на тэрыторыі Літвы і Беларусі было адменена y̆ 1840 г., то сам ён не мог памятаць гэтай падзеі, і таму ў пачатку $\mathrm{XX}$ ст., натуральна, выказваўся па гэтай тэме не як сведка падзеі, а як гісторык - на падставе засвоеных ад іншых асоб уяўленняў або ўзятых з літаратуры ведаў. У любым выпадку, Т. Корзан усведамляў, што для яго «rodzime» - гэта літоўскае, а расійскае, трэба разумець 3 кантэксту, - чужое. Пры гэтым літоўскае ў Т. Корзана не знаходзіцца ў апазіцыі да польскага. Успамінаючы пра сваё жыццё канца 1840-х гг., Т. Корзан фіксуе, на якіх гістарычных ідэалах яго выхоўвалі: «Ојсіес opowiadał mi o zwycięstwie Jagiełły i Witolda pod Grunwaldem, albo o dziadku, po którym pozostaly części munduru i ladownica kawalerzysty petyhorskiego, albo o dawnych swobodach, utraconych przez lekkomyślność szlachty przy nadmiarze szczęścia» ${ }^{18}$. Ягайла і Вітаўт былі сімваламі сярэдневяковай польскай і літоўскай дзяржаўнасці, а «пяцігорцамі» называлі лёгкую кавалерыю, назва якой паходзіла ад чаркесаў (пяцігорцаў) або, магчыма, татар, і якая была часткай войска ВКЛ.

У польскамоўнай літаратуры XIX - першай паловы XX ст. можна сустрэць назву горада Мінска ў форме Mińsk Litewski. Гэта

\footnotetext{
${ }^{17}$ T. Korzon, Mój pamiętnik..., s. 4.

${ }^{18}$ Ibidem, s. 22.
} 
было звязана $з$ прыналежнасцю горада да Літвы, у той час як існнаваў яшчэ адзін Мінск - Mińsk Mazowiecki. Другая частка з'яўлялася пры назвах гарадоў былой Рэчы Паспалітай, якія паўтараліся ў розных кутках гэтай дзяржавы: Brześć Litewski i Brześć Kujawski, Kamieniec Litewski i Kamieniec Podolski і г. д. Форма Mińsk Litewski выкарыстоўвалася не толькі ў друку. Так, напрыклад, на адваротах фатаграфій, якія рабілі да 1863 г. першыя мінскія фатографы Антоні Прушынскі, Альфонс Дэльпацэ, змешчаны фірменныя знакі з надпісамі: «Zakład fotograficzny A. Prószyńskiego w Mińsku Litewskim», «Zakład fotograficzny Alphonsa Delpace przy Zacharzewskiej ulice № 16 w Mińsku Litewskim». Аднак у той жа час функцыянавала і назва Mińsk: «Zakład fotograficzny Alphonsa Delpace na Zacharzewskiej ulice № 16 w Mińsku» ${ }^{19}$.

У перыядычным друку пачатку XX ст. можна было спаткаць такія тлумачэнні назвы горада: «Mińsk, zwany także Mińskiem Litewskim, w dokumentach łacińskich Minscum, w słow. Mieńsk, Mińsko, w narzeczu ludowym Miensk» ${ }^{20}$. Гэта было па-сутнасці паўтарэннем ранейшых публікацый - напрыклад, энцыклапедычнага артыкула Аляксандра Ельскага, выдадзенага ў 1885 г.: «Mińsk, zwany także Mińskiem Litewskim, w dokum. łacińskich Minscum, w słow. Miensk, Minsko, w narzeczu ludowym Miensk» ${ }^{21}$.

Дапускаю, што менавіта А. Ельскаму трэба аддаць належнае за адраджэнне старажытнай назвы горада. Першай кнігай на беларускай мове, дзе назва горада выкарыстана ў форме Менск («у Мънску-Литоўскамъ»), з'яўляецца праца А. Ельскага «Выби-

${ }^{19}$ Мінск і мінчане: дзесяиь стагоддзяў гісторыі. Крыніцы па гісторыі горада. Сацььяльныя структуры $i$ паўсядзённасиьь (да 945-годдзя Мінска): зборнік навуковых артыкулай, уклад. А. І. Груша; рэдкал.: А. А. Каваленя і інш., Мінск 2012, уклейка паміж сс. 302-303; 3. Дрозд, Таямніџы Дуніна-Мариінкевіча, Vilnius 2018, уклейка паміж сc. 60-61.

${ }^{20}$ Mińsk, «Tygodnik Wileński» 1911, nr 13, 27 marca (9 kwietnia), s. 3.

${ }^{21}$ A. Jelski, Mińsk [w:] Stownik geograficzny Królestwa Polskiego i innych krajów stowiańskich. T. VI, red. F. Sulimierski, B. Chlebowski, W. Walewski, Warszawa 1885, s. 453. 
Віктар Корбут, Ідэнтычнасць жыхароў Мінска ў XIX - пачатку XX ст... 135

раймася у прочки»! «Скарэй у Томскъ»!!», якая выйшла ў 1896 г. у Санкт-Пецярбургу 22.

У першым нумары першай беларускай газеты «Наша Доля» („Nasza Dola”) - 1 верасня 1906 г. - Мінская губерня названа «Менск. губ.» („Miensk. hub.”).

Такім чынам, першымі выпадкамі выкарыстання назвы Менск у беларускім друку трэба лічыць кнігу А. Ельскага 1896 г. і першы нумар віленскай першай беларускай газеты «Наша Доля» (,Nasza Dola”) за 1906 г. Аднак у яе другім нумары ўжо выкарыстоўваецца форма Мінск: Минской губ. = Minskoj hub. У трэцім нумары ў розных версіях - рускімі і польскімі літарамі - два варыянты: з Минскаго повету = z Mienskaho pawietu. У пятым нумары: Minsk, Minskaja hub.; у шостым - Минскай губэрни.

У першым нумары віленскай беларускай газеты „Nasza Niwa” за 1906 г.: u Mienskoj huberni, аднак у другім ужо: Minsk, у чацвёртым $-\mathrm{u}$ Minskoj hub.

Літва ўспрымалася польскамоўнымі мінчанамі не ў этнічным, а ў геаграфічным сэнсе, трэба меркаваць, як працяг ідэнтычнасці шляхецкага саслоўя, сфарміраванай у часы Вялікага Княства Літоўскага. Адначасова польскамоўнае грамадства Мінска адчувала моцную духоўную сувязь з іншымі рэгіёнамі Літвы і землямі ўласна Польшчы, што тлумачыцца агульнасцю рэлігіі (каталіцтва, уніяцтва), мовы (польская) і гістарычнай памяці (Вялікае Княства Літоўскае, Рэч Паспалітая).

Такім чынам, выкарыстанне формы Mińsk Litewski было ўласціва прадстаўнікам польскамоўнай культуры з мэтай, з аднаго боку, падкрэсліць знаходжанне горада «ў Літве», а з другога, адрозніць яго ад Мінска-Мазавецкага.

Можна сцвярджаць, што польская ідэнтычнасць шляхты ў Мінску і ўвогуле ў Літве (у т. л. у Беларусі) была ў ХІХ ст. праявай

${ }^{22}$ «Выбираймася у прочки»! «Скарэй у Томскъ»!! Абъ тоя добра развъдаў и разтлумачыў народу А. І., Пицярбурхъ: Складъ глаўны у книжницы Б. Адамовича, у Мънску-Литоўскамъ, 1896. 
мясцовага патрыятызму і ў той жа час арыентацыі на адзінства 3 арыстакратыяй усёй былой Рэчы Паспалітай. Мабыць, правільна было б у польскасці таго часу бачыць не толькі нацыянальны змест, а і моцную сацыяльную, саслоўную аснову.

I тым не менш, нацыянальная свядомасць была моцным інтэграцыйным фактарам для палякаў Мінска, а яе вонкавай праявай - польская мова. Бацька Т. Корзана дбаў пра тое, каб сын дасканала валодаў польскай літаратурнай мовай - «z udzielanej mi poprzednio przez ojca nauki języka polskiego podług króciuchnej gramatyki Ks. Adama Krasińskiego, Pijara, późniejszego biskupa Wileńskiego» ${ }^{23}$.

Нельга, вядома, не адзначыць у той жа час пэўнага адзінства сацыяльных інтарэсаў мінскага польскага дваранства з уладамі Расійскай імперыі. Як адзначае 3. Кавалеўская, а таксама следам за ёй гісторык Усевалад Ігнатоўскі, калі ў 1858 г. расійскі імператар Аляксандр II прыязджаў у Мінск, для яго было заказана ўрачыстае набажэнства ў кафедральным касцёле, арганізаваны баль тутэйшай шляхтай. I гэта было не толькі выяўленне фармальнай павагі да першай асобы ў дзяржаве. 3. Кавалеўская сведчыць: «Przyjazd Cesarza budził wśród wybitniejszego ziemiaństwa pewne polityczne nadzieje i że ono wysadzało się na jego przyjęcie, manifestując szczerze swe uczucia, wiecznie wypływające z ugodowych krynic, któremi polityczny rozum miejscowych dyplomatów był przesiąknięty» ${ }^{24}$. Аднак Аляксандр II не апраўдаў надзей мінскай польскай арыстакратыі.

У канцы лістапада 1862 г. адбыўся з'езд шляхты Мінскай губерні. Адной з мэт з'езда была падача адраса цару з просьбай аб далучэнні губерні да Польшчы. Такі ж адрас ужо падавала шляхта Падольскай губерні (Украіна). Міхаіл Мураўёў, які з 1863 г. заняў пасаду віленскага генерал-губернатара і задушыў Студзеньскае

${ }^{23}$ T. Korzon, op. cit., s. 25.

${ }^{24}$ Z. Kowalewska, op. cit., s. 73-74; У. Ігнатоўскі, 1863 год на Беларусі [y:] Idem, Bыбранае, укл. Г. Запартыка, навук. рэд. І. Саверчанка, Мінск 2018, с. 418-419. 
паўстанне ў Літве і Беларусі, успамінаў, што «менскае шляхецтва адзначалася яшчэ большаю нянавісцю да расійскага ўрада, чым у іншых губернях». Ён дадаваў, што «калі ім [шляхце. - B.K.] вызначана было загадам ад улады, што такі ўчынак процізаконны, яны не скасавалі сваёй пастановы, але запісалі яе ў пратакол, зазначаючы, што не давялі яе да канца толькі дзеля забароны гэтага з боку вышэйшай улады». Гісторык Усевалад Ігнатоўскі ўдакладняў, што «найбольш агітавалі за падачу адраса землеўласнікі - два браты Яленскія, двое Аскеркаў і Корбут. Яны матывавалі неабходнасць падачы адраса тым, што гэтага вымагаюць неадкладныя інтарэсы краю. Тым больш, што іншыя паўночна-заходнія губерні імперыі пададуць палітычныя адрасы, а гэта зробіць вялікім сорам для шляхты Менскай губерні, калі яна не падасць адраса».

Далучэнне да Польшчы мясцовая мінская арыстакратыя разумела як шлях да незалежнасці ад Расіі, як аднаўленне старой дзяржаўнасці - супольнай з Польшчай. Гэта было жаданне аднавіць адзінства польскай шляхецкай нацыі, падзеленай на той час не толькі паміж Расіяй, Аўстрыяй і Прусіяй, але і ўнутры Расіi.

Гэта было змаганне ў нейкім сэнсе і за Беларусь, Літву, Украіну (не за нацыі, а за тэрыторыі), але ў складзе Польшчы. Як бы пайшло жыццё ў складзе Польшчы, гэта іншае пытанне. Але мэтай змагання было жыццё не ў Расіi. Як піша У. Ігнатоўскі, «праз некалькі дзён праект адраса быў надрукаваны і пашыраны па гарадах Беларусі», а таксама «вельмі хутка ў Менску з'явіліся прылепленыя на рагах вуліц вершаваныя сатыры-эпіграмы на мясцовых магнатаў-землеўласнікаў, аб якіх гаварылася, што яны маюць шмат усяго, апроч адвагі і патрыятызму». Меліся на ўвазе тыя арыстакраты, якія займалі згодніцкую пазіцыю з расійскім урадам ${ }^{25}$.

Тое, што мясцовая польская нацыя, або значная яе частка, была настроена супраць Расіi, было цалкам натуральна, бо нацыя А не магла не быць настроена апазіцыйна, варожа да нацыі В, якая паз-

\footnotetext{
${ }^{25}$ Ibidem, c. 491-492.
} 
бавіла нацыю А сваёй дзяржаўнасці (Рэчы Паспалітай) і права гаспадарыць самастойна на сваёй зямлі (працэс «дэпаланізацыі» ў той ці іншай меры актывізаваўся пасля 1812 г. і асабліва пасля 1831 г.). Пачатак 1860-х гг. адзначыўся дэманстрацыямі жыхароў Мінска, якія выказвалі польскія патрыятычныя пачуцці, што было звязана 3 антырасійскімі хваляваннямі ў Польскім Каралеўстве.

Паводле 3. Кавалеўскай, «w listopadzie 1861 r. uczniowie [Мінскай мужчынскай гімназіi. - B.K.], obchodząc rocznicę 1831 r., zakupili nabożeństwo w katedrze [цяпер пл. Свабоды, 9. - B.K.] o piątej rano, a po odśpiewaniu hymnów, rozeszli się spokojnie, nie ukazując się wcale dnia tego w klasach. Dyrektor, nie nadając temu wielkiego znaczenia, zachował się biernie, ale władze administracyjne podniosły alarm, żądając usunięcia 20 uczniów z gimnazjum, czemu się jednak dyrekcja opierała $\rangle^{26}$.

У 1862 г. мінскае польскае грамадства ўдзельнічала ў патрыятычных маніфестацыях: «Z uchem zwróconem ku zachodowi, społeczeństwo polskie, okryte żałobą, w czamarach i konfederatkach, śpiewało narodowe hymny i antyfony, przesuwając się procesją z kościoła do kościoła» ${ }^{27} .20$ жніўня 1861 г. у кафедральным касцёле адбыліся «рэвалюцыйныя спевы», у якіх удзельнічала да 300 чалавек. Многіх з іх арыштавалі за тое, што выконвалі рэлігійную песню «Воże! Coś Polskę...». Увосень гэтакія дэманстрацыі сталі частай з'явай ${ }^{28}$. За спеў у кафедральным касцёле 10 верасня 1861 г. патрыятычнага гімна абвінавачваліся Анеля Галоўня з дочкамі Розай і Феліцыяй, Караль Няміра (яны ўдзельнічалі ў спевах 20 жніўня), сёстры Філіпіна і Канстанцыя Гейдукевіч, фатограф Антоні Прушынскі. Усяго ў спевах узялі ўдзел каля 100 чалавек. Яны выконвалі рэлігійную песню, дзе замест слоў «Do Twego tronu zanosim błaganie,

${ }^{26}$ Z. Kowalewska, op. cit., s. 87.

${ }^{27}$ Ibidem, s. 89.

${ }^{28}$ А. Э. Фірыновіч, Матэрыялыь фонду «Мінскага павятовага суда» Нацььянальнага гістарычнага архіва Беларусі аб падзеях у Мінску напярэдадні паўстання 1863-1864 г2. [у] Мінск і мінчане..., с. 267-268. 
Віктар Корбут, Ідэнтычнасць жыхароў Мінска ў XIX - пачатку XX ст... 139

w opiekę swoją racz nas przyjąc, Panie» гучалі гэтакія: «Przed Twe ołtarze zanosim błaganie, Ojczyźnie wolność racz nam wrócić, Panie» ${ }^{29}$. 27 жніўня 1861 г. у касцёле Святога Юзафа Абранніка Найсвяцейшай Панны Марыі (цяпер вул. Кірыла і Мяфодзія, 4) адбыліся «рэвалюцыйныя спевы». 3 кастрычніка 1861 г. патрыятычны спеў разам 3 жалобным набажэнствам паўтарыўся. Цырымонія адбывалася ў цемры. Гэта было сродкам пазбегнуць кары, бо ўлады забаранялі такія мерапрыемствы ${ }^{30}$.

31 ліпеня 1862 г. аб 11.00 адбылася польская патрыятычная дэманстрацыя жыхароў Мінска: яны прайшлі ў польскіх убраннях па вуліцах горада да касцёла Святога Юзафа Абранніка Найсвяцейшай Панны Марыі. У храме пасля набажэнства ля вялікага алтара ксёндз Шукевіч заспяваў «рэвалюцыйны гімн». Яму дапамагалі фартэпіяніст Бяляўскі, унтэр-афіцэр Арэнбургскага пяхотнага батальёна шляхціц Гадзеўскі і адстаўны чыноўнік Юльян Гарбатоўскі. Улады спрабавалі прыцягнуць іх да адказнасці, але не знайшлі сведак ${ }^{31}$. У 1864 г. улады гэты храм прыстасавалі пад праваслаўную царкву ў імя Святых Кірыла і Мяфодзія Каломенскага пяхотнага палка. Франтон разабралі, дах панізілі. Пазней у будынку размясціўся «Сосредоточенный архивъ упраздненныхъ судебныхъ мъстъ Минской губерніи» ${ }^{32}$. І дагэтуль тут знаходзяцца архівы $^{33}$.

T. Корзан успамінае пра адну рэдкую праяву польскай нацыянальнай ідэнтычнасці сярод жыхароў Мінска, якую назіраў, відавочна, не пазней за 1863 г.: «Widywałem staruszka Rogowskiego

${ }^{29}$ Ibidem, c. $267-268$.

${ }^{30}$ Ibidem, c. 267-269.

${ }^{31}$ Ibidem.

${ }^{32}$ В. Н. Денисов, Площчадь Свободы в Минске, Минск 1985, с. 51; Каталіиякія святыні. Мінска-магілёуская архідыящээія. Ч. 1. Будслаўскі, Вілейскі і Мінскі дэканаты, тэкст і фота А. Яроменкі, уводзіны У. Трацэўскага, Мінск 2003, с. 211; Корбут В. А., op. cit., с. 214.

${ }_{33}^{33}$ В. А. Корбут, Д. М. Ласько, Мінск. Спадчына старога горада. 1067-1917, Мінск 2016, с. 109. 
w polskim stroju, acz bez karabeli, chodzącego po ulicach Mińska w tym czasie, kiedy starodawne mody były prześladowane bezwzględnie» ${ }^{34}$.

Мінскія палякі адчувалі, відавочна, духоўную сувязь, адзінства з суайчыннікамі з-над Віслы. Нельга ставіць пад сумненне той факт, што асновай гэтых адчуванняў была агульная нацыянальная свядомасць - польская. Пра нацыянальную салідарнасць мінчан 3 жыхарамі Польскага Каралеўства ў 1863 г. сведчыць 3. Кавалеўская: «W końcu lutego ciężkie wrażenie ogarnęło ludność polską w Mińsku, gdy przed dom gubernatora [пл. Свабоды, 7. - B.K.], pod silną strażą, zajechał wóz, pełen powiązanych ludzi. Był to pierwszy transport więźniów ze stron dalszych. Nikt bowiem tych młodych a zmęczonych twarzy nie znał w mieście wcale» ${ }^{35}$. Нацыянальная салідарнасць падчас Студзеньскага паўстання сярод мінскіх палякаў назіралася не толькі на дэманстрацыях, але і ў канкрэтных дзеяннях: «Realne tylko kształty objął utworzony komitet w celu niesienia pomocy wygnańcom z Królestwa, prowadzonym przez Mińsk, w głąb Rosji i Sybiru. Komitet ten składali: Władysław Dmochowski, Karol Stankiewicz, Michał Dobrowolski, Piotr Czekotowski, Nowakowski i wielu innych panów i pań, z których najczynniejszemi były: Kamila Marcinkiewiczówna [дачка пісьменніка В. Дуніна-Марцінкевіча. - B.K.], Okołołówna, Rulewska i wiele innych. Komitet bywał zawsze uprzedzony o chwili przybycia partji więźniów z nad Wisły i spotykał ją, zaopatrując w pieniądze, bieliznę, żywność i inne potrzeby» ${ }^{36}$.

Не будзе лішнім яшчэ раз падкрэсліць, што 3. Кавалеўская разглядала падзеі ў Мінску ў цеснай сувязі з тымі працэсамі, якія адбываліся ў жыцці палякаў як у Польскім Каралеўстве, так і ў Літве: «Dnia 22 maja nowy dreszcz zgrozy przejął polski ogół w Mińsku. Oto nadbiegła wiadomość o śmiertelnej znów kaźni ks. Iszory w Wilnie, a zaraz potem o rozstrzelaniu ks. Falkowskiego w Lidzie...» ${ }^{37}$.

\footnotetext{
${ }^{34}$ T. Korzon, op. cit., s. 13.

${ }^{35}$ Z. Kowalewska, op. cit., s. 101.

${ }^{36}$ Ibidem, s. 90.

${ }^{37}$ Ibidem, s. 120.
} 
Поўныя трагізму словы з'яўляюцца ў запісках 3. Кавалеўскай, калі яна апісвае падзеі мая 1863 г.: «Straszne przygnębienie ogarnęło ogół polski w Mińsku. Duch, w ciągłej walce z nadzieją i niepowodzeniem, łamał się i upadać zaczynał» ${ }^{38}$. У гэтых словах адлюстраваны той гістарычны момант, пасля якога «польскі» Мінск пачынаў пад уплывам знешніх фактараў змяняць свой воблік, страчваючы польскія рысы.

3. Кавалеўская, апісваючы рэпрэсіі супраць удзельнікаў Студзеньскага паўстання, адзначае, што ў гэты час кляштары пераўтвараліся ў турмы. Так, напрыклад, арыштаваных удзельнікаў паўстання «osadzono w klasztorze Benedyktynek, który po usunięciu kilku pozostałych zakonnic, zamieniony został na więzienie polityczne» ${ }^{39}$. У 1863 г. у турму для паўстанцаў быў пераўтвораны таксама кляштар бернардзінцаў (вул. Кірыла і Мяфодзія, 6), пасля там знаходзіліся казармы Каломенскага пяхотнага палка, вайсковая камендатура, а з 2014 г. - гатэль ${ }^{40}$. Такім чынам, канфіскаваная ў 1863 г. уласнасць каталіцкага касцёла ў Мінску дагэтуль яму не вернута, што сведчыць пра доўгатэрміновы эфект вынікаў няўдалага паўстання.

Пасля паўстання 1863 г. сярод часткі мінскай арыстакратыі, якая не была рэпрэсіравана і засталася жыць у горадзе, з'явіўся скепсіс у адносінах да таго, ці магчыма аднаўленне грамадскага ладу і культурнай сітуацыі, якая склалася да 1863 г. Гэта даводзіла некаторых прадстаўнікоў мясцовага польскага соцыуму да фрустрацы. Несумненна, гэта было абумоўлена і сацыяльнымі фактарамі, патрэбай прыстасавацца да сістэмы, каб выжыць. Т. Корзан захаваў паказальныя ўспаміны пра той перыяд: «Nasz przyjaciel musiał zapisać się na wiarę prawosławną, chociaż był w duszy gorliwym katolikiem, mial żonę rzymsko-katolickiego wyznania, córkę ochrzczoną po katolicku, a syna prawosławnego. [...] Z jakąż goryczą wyrzekał na

\footnotetext{
${ }^{38}$ Ibidem, s. 114.

${ }^{39}$ Ibidem, s. 102.

${ }^{40}$ В. А. Корбут, Д. М. Ласько, op. cit., с. 113.
} 
Polaków za to, że kraj własny zgubili! Będąc z uczuć i z pojęć Polakiem, pamiętając Mińsk jako miasto polskie, nie przypuszczał wcale możliwości odtworzenia rządów polskich i, urzędując w biurze po rosyjsku, marzył poza biurem tylko o niebieskiej ojczyźnie» ${ }^{41}$. Такім чынам, частка мясцовай арыстакратыі, каб атрымаць пасады, была вымушана «змяняць» сваю знешнюю ідэнтычнасць, аднак польская мова і культура заставаліся ў сямейным жыцці: «Nawet duchowieństwo prawosławne, o ile składało się z osób miejscowego pochodzenia, zachowywało w domu mowę i obyczaje polskie» ${ }^{42}$.

Тым не менш, і пасля 1863 г. у жыцці Мінска польская мова і культура займалі прыкметнае месца. I ўзмацнялася іх значэнне як сімвалаў мясцовага патрыятызму. Так, калі ксёндз Макарэвіч у касцёле Найсвяцейшай Тройцы на Залатой Горцы (цяпер пр. Незалежнасці, 44a) у другой палове XIX ст. пачаў чытаць казані па-руску, то «nabożeństwo w obcej mowie raziło lud»: «Jak zwykle kościoły, gdzie obca brzmiała mowa, tak i ten - bojkotowano. [...] ...A gdy ksiądz Makarewicz zaczynał śpiewać litanję w obcej mowie, cały lud potężnym głosem, jeszcze potężniejszym niż zwykle, odpowiadał po polsku» ${ }^{43}$. Паводле 3. Кавалеўскай, у 1869 г. «znalazł się w roli proboszcza na Złotej Górce ks. Zauścinski, takiż, acz mniej szkodliwy odszczepieniec, który w dniu 15 maja miał pierwszą mszę dla uczniów w języku rosyjskim. Próba ta jednak, pomimo przymusu, wywieranego na szkolną młodzież, - nie dała pożądanych rezultatów i zaniechaną być musiała» ${ }^{44}$.

Праводзячы русіфікацыю, расійская адміністрацыя цудоўна ўсведамляла, што «туземцы» - гэта палякі, а рускія - гэта перш за ўсё прышлы элемент, які прыбываў у Літву (або, як у той час яшчэ гаварылі пра тэрыторыю сучасных Літвы і Беларусі, «в Польшу») ${ }^{45}$.

${ }^{41}$ T. Korzon, op. cit., s. 4.

${ }^{42}$ Ibidem, s. 6.

${ }^{43}$ Nasze Kościoły. Djecezja Mińska. T. 2. Zesz. 11, red. J. Żyskar, Warszawa 1913, s. 11.

${ }^{44}$ Z. Kowalewska, op. cit., s. 126.

${ }^{45}$ У. Ігнатоўскі, op. cit., с. 593-594. 
Але і сярод палякаў у той час былі як мясцовыя, так і выхадцы з Польскага Каралеўства. Як успамінае А. Багдановіч, вясной 1876 г. «по приезде в Минск» 3 бацькаўшчыны, Халопеніч, яго хацелі адправіць на вучобу «на Юрьевскую [вуліцу. - B.K.] к ножевщику, поляку Озембловскому», у майстэрні якога ўсё было «по-польски и на польский лад»: «Пан майстэр Озембловский повел меня в кузницу, где представил подмастерьям, называя их: пан Стэфан, пан Игнацы и пр.» ${ }^{46}$. А «на следующий день мы отправились к слесарю Минкевичу, тоже поляку из Варшавы, имевшему дом и мастерскую на берегу Свислочи, у Полицейского моста» ${ }^{47}$. Пэўны час А. Багдановіч (прыкладна да 1878 г., калі яму споўнілася 16 год ${ }^{48}$ ) працаваў у цукерні Роберта Шэнінга на вул. Петрапаўлаўскай (цяпер вул. Энгельса $)^{49}$. Паводле ўспамінаў А. Багдановіча, «кондитерская была варшавского типа: нечто вроде свободного клуба. [...]

На варшавский же манер - хозяин назывался «принципалом», и так к нему вменялось обращаться: пане принципал $[\ldots]\rangle^{50}$.

Польскі моўна-культурны комплекс у Мінску па-ранейшаму захоўваў моцныя пазіцыі. Нават у беларускую мову сялян, якія прыязджалі ў Мінск, пранікалі польскія назвы гарадскіх рэалій, пра што сведчаць успаміны А. Багдановіча. Ён цытуе ўражанні сваёй маці Анелі ад наведвання Мінска ў 1860-я гг.: «Много она насмотрелась на разные чудеса: «брукаваные» улицы (мощеные камнем), «трантавары» (тротуары) по сторонам, фонари на улицах, словно иллюминация постоянная, каменицы, архиерейский дворец, консистория, губернаторский дом, церкви, костелы, нижний, верхний и рыбный рынки, торги на Траецкой гарэ, Злота Гурка, сады и бульвары» ${ }^{51}$.

\footnotetext{
${ }^{46}$ А. Е. Богданович, op. cit., c. 456.

${ }^{47}$ Ibidem, c. 457.

${ }^{48}$ Ibidem, c. 474.

${ }^{49}$ Ibidem, c. 7.

${ }^{50}$ Ibidem, c. 467.

${ }^{51}$ Ibidem, c. 368.
} 
Паводле А. Ельскага, к 1885 г. культурны выгляд горада ўжо значна змяніўся. Польская тэатральная сцэна не існавала ўжо на працягу 20 гадоў. Дзейнічалі польскія кнігарні Аляксандра Валіцкага (пазней яго сястры Зоф'і Савіцкай), Б. Гадлеўскага, іншыя былі яўрэйскія. У Мінску дзейнічалі чатыры друкарні, але з 1863 г. яны амаль не выдавалі кніг па-польску ${ }^{52}$.

Т. Корзан успамінаў, як пасля 1863 г. адбывалася русіфікацыя гарадской прасторы: «Nawet ulica Franciszkańska, biegnąca od byłego kościoła w górę, ku centrowi miasta, dziś się już Gubernatorską mianuje. Znikną też wkrótce, gdy starsze pokolenie wymrze i ślady kościołów i klasztorów, zniesionych po 1863 r. [...] Kościół i klasztor Dominikanów obrócony został na koszary dla żołnierzy. Ulica też Dominikańska, nosząca od kościoła swą nazwę, dziś przechrzczona została na Pietropawłowską) ${ }^{53}$.

На мяжы XIX i XX стст. польская культура не магла свабодна развівацца ў Мінску. Але ў эканамічным жыцці Літвы і Беларусі, як і ў кіраўніцтве Мінска дамінуючае становішча займалі мясцовыя арыстакраты - палякі, напрыклад, граф Караль Ян Аляксандр Чапскі (1890-1901), Станіслаў Хржанстоўскі (1909-1917). Як адзначае даследчык гісторы Мінска таго перыяду Захар Шыбека, «у сваёй дзейнасці ў якасці гарадскога галавы Хржанстоўскі, як i Чапскі, арыентаваўся пераважна на мясцовую буржуазію каталіцкага веравызнання. Абараняючы яе інтарэсы, дамагаўся ўсталявання сяброўскіх адносін з паліцмайстрамі і губернатарамі. У той жа час яму было ўласціва разуменне агульнасці класавых інтарэсаў буйной буржуазіі горада, да якой бы веры або нацыянальнасці яна не належала» ${ }^{54}$. Класавыя інтарэсы вяршкоў мінскага польскага грамадства пасля 1863 г. пераважалі над іх нацыянальнымі інтарэсамі, хаця і не ўступалі ў відавочную супярэчнасць. Гэта сацыяль-

${ }^{52}$ A. Jelski, op. cit., s. 455.

${ }^{53}$ T. Korzon, op. cit., s. 45.

${ }^{54}$ 3. В. Шибеко, Минск. Страницьь жизни дореволюциионного города, Минск 1990, c. 49. 
Віктар Корбут, Ідэнтычнасць жыхароў Мінска ў XIX - пачатку XX ст... 145

ная афарбоўка мясцовага «polskiego ogółu», карыстаючыся выразам 3. Кавалеўскай, захоўвалася, як мы бачым з цытаваных успамінаў, 3 перыяду, які папярэднічаў драматычным падзеям 1863 г.

Дзякуючы багаццю і ўладзе мясцовым польскім арыстакратам удавалася захоўваць у Мінску прысутнасць польскага нацыянальнага элемента. Мінскі праваслаўны архіепіскап Міхаіл, які прыбыў у горад ў 1899 г., абвінавачваў мінскага гарадскога галаву Стэфановіча і мінскага губернатара Эрдэлі ў прапольскай арыентацыі ${ }^{55}$. Але пазіцыі польскага элемента ў Мінску ў пачатку XX ст. былі слабейшыя, чым у 1863 г.

Тое, які воблік набыў Мінск к 1910-м гг., адлюстравала 3. Кавалеўская: «Mińsk też dzisiejszy i ówczesny, to dwa miasta odmiennego typu i charakteru. Obcym dziś porostem pokryte miasto, już innym nasiąkłe jest duchem. Element polski ginie tu niemial wśród innych narodowości. Rozrośli i zbogaceni żydzi, szwargocząc skażoną mową rosyjską, zalewają miasto, kłaniając się nowym, silniejszym bogom. Tworzą oni nowy całkiem typ, różniący się wielce od typu swych dziadów.

Dawne stare świątynie znikły z horyzontu. W kościele i klasztorze Dominikańskim mieszczą się koszary, u Bernardynów - archiwa i remizy straży ogniowej, u Benedyktynek - zakonnice prawosławne i cerkiew w miejscu kościoła. Nazwy ulic zupełnej też uległy zmianie. Przypominamy je tym młodszym, które je dziś depcą i deptać potem będą.

Ulica Franciszkańska, pryncypalna w owych czasach, biorąc swą nazwę od kościoła, dawno już nieistniejącego, Franciszkanów, w dolnej części miasta, ku Niemizie, - od 1864 r. zowie się ulicą Gubernatorską. Ulica Zborowa, bieżąca od placu Katedralnego ku więzieniu miastowemu, tak zwana od Kalwińskiego Zboru, który tam istniał w XVII stuleciu, - dziś się nazywa Preobrażeńską. Przeciwległa zaś tej, wiodąca od tegoż placu w dół, ku Świsłoczy, dawna ulica Wołoska, - obecnie mianuje się Kreszczeńską.

\footnotetext{
${ }^{55}$ Ibidem, c. 50.
} 
Ulica Dominikańska, nosząca swą nazwę od byłego kościoła Dominikanów, - przechrzczoną została na Petropawłowską. Ulica zaś Felicyańska, idąca około starej polskiej instytucji, Dobroczynnością zwanej, - nosi dziś nazwę Bogodzielnej.

Podobnej przemianie nazw uległa i większość drobniejszych arterji miasta, których starodawne miano ginie już zupełnie w niepamięci ludzkiej... [...]

Pod obecną powłoką trudno rozpoznać Mińsk dawny, ale stare nazwy i pamiątki archeologiczne znać należy i nie dać im zaginąć bezpowrotnie» ${ }^{56}$.

Як успамінаў Я. Булгак, яго калега Ф. Рушчыц падчас візіту ў горад ў пачатку 1911 г. для падрыхтоўкі тут польскай мастацкай выстаўкі (прайшла 12(25) - 23 сакавіка (5 красавіка) 1911 г.), зрабіў замалёўкі Мінска для часопіса «Tygodnik Wileński». Гэтыя малюнкі адлюстроўвалі крытычнае становішча польскага элемента ў горадзе: «Narysował w «Tygodniku» wytworny rokokowy szczyt dawnego kościoła, przerobionego przez Rosjan na koszary i uwieńczonego nędzną nadbudówką drewnianą w cynicznym stylu «kolejowym» i podpisał: «Dawny kościół Dominikański, dziś «kałancza», rysunek z natury». Aobok umieścił fragment kamienicy frontowej zgłównejulicy, dosłownie opancerzonej paskudnemi żydowskiemi szyldami potwornej wielkości i znów podpisał: «Jedno z upiększeń ulicy Gubernatorskiej - rysunek z natury». Dla nas komentarze były niepotrzebne, ale najzabawniejsze jest, że Rosjanie z pewnością nie rozumieli ironji tych ilustracji i brali teksty za dobrą monetę» ${ }^{57}$. Паводле Я. Булгака, у Ф. Рушчыца быy̆ сантымент да Мінска - «rodzinnego miasta», у сувязі з чым ён хацеў прысвяціць і прысвяціў яму спецыяльны нумар часопіса «Tygodnik Wileński» ${ }^{58}$. На старонках часопіса Ф. Рушчыц так апісваў Мінск: «Długie szeregi mniejszych lub większych domów, przypadkowo usta-

${ }^{56}$ Z. Kowalewska, op. cit., s. 127-128.

${ }^{57}$ J. Bułhak, Dwadzieścia sześć lat z Ruszczycem, Wilno 1939, s. 39-40.

${ }^{58}$ Ibidem, s. 33, 39. 
wionych wzdłuż bezdusznie trasowanych ulic, zasłoniły dawną fizjonomję miasta.

Jedna z niewielu wysp, ocalałych śród tej powodzi, to Katedra i mury ją otaczające, dzieniegdzie jeszcze jakaś kamienica o tradycyjnem poważnem obliczu, dalej piękny nowy kościół.

$\mathrm{Na}$ ulicach dalszych nieliczne już siedziby typu dawnych, drewnianych, przeznaczonych dla użytku jednej rodziny, rozłożystych, wygodnych dworków». Ф. Рушчыц рабіў вывад: «А ziemia ta - to ziemia od wieków użyźniona kulturą naszą» ${ }^{59}$.

Больш падрабязна ўмовы развіцця польскай мовы і культуры ў Мінску ў 1863 г. - пачатку XX ст. разгледжаны ў працах Тадэвуша Зянкевіча і Дарыюша Тарасюка ${ }^{60}$.

Увогуле ж, сантыменты да Мінска сярод прадстаўнікоў польскай культуры, якія паходзілі з горада або яго ваколіц, захоўваліся прынамсі да канца 1930-х гг. Пра гэта красамоўна сведчаць словы, сказаныя фатографам Янам Булгакам у 1939 г., калі Менск знаходзіўся на самай граніцы 3 тагачаснай Польшчай. Я. Булгак выказваў жаль у сувязі з тым, што горад застаўся, як ён выказаўся, «W granicach imperium bolszewickiego [...] wraz z ludźmi, pamiątkami i z ziemią, przepojoną polskością» ${ }^{61}$.

\section{«Żydostwo posługiwało się w stosunku z miejscową ludnością jedynie polskim językiem»}

Ва ўспрыманні 3. Кавалеўскай польская ідэнтычнасць жыхароў Мінска, у тым ліку іх ментальная, моўна-культурная паланізацыя выглядала як норма. Напрыклад, апісваючы быт мінскай арыста-

${ }^{59}$ o-K-o, op. cit., s. 3.

${ }^{60}$ T. Zienkiewicz, Polskie życie literackie w Mińsku na początku XX w. (do r. 1921), Olsztyn 1997; D. Tarasiuk, Między nadzieja a niepokojem. Działalność społeczno-kulturalna i polityczna Polaków na wschodniej Białorusi w latach 1905-1918, Lublin 2007.

${ }^{61}$ J. Bułhak, op. cit., s. 40. 
кратыі да 1863 г., мемуарыстка расказвае пра маршалка шляхты Мінскай губерні Оштарпа (Osztorp): «Pochodził również z cudzoziemskiej, szwedzkiej, jak się zdaje, lecz już spolonizowanej rodziny» ${ }^{62}$.

Тое, што «сваімі» людзьмі да 1863 г. лічыліся абавязкова польскамоўныя, падкрэслівала характарыстыка мінскіх яўрэяў: «Mińsk liczył podówczas około 35-40 tysięcy ludności, połowę której stanowili izraelici, zachowujący jeszcze swe typowe cechy oraz pewną życzliwość dla miejscowej ludności, czego dziś już niema. Nie posiadali jeszcze wówczas takich, jak dziś kapitałów i takiej arogancji, a interesy swe łączyli z interesami kraju» ${ }^{63}$. Што гэта за «інтарэсы»? 3. Кавалеўская ўдакладняе: «Mówili tylko po polsku, manifestując niejednokrotnie w czynach swą dla nas sympatję. Dopiero po 1863 r. postrzegłszy słabość zwyciężonych a siłę zwycięzców, silę, która im ułatwiała zbierać fundusze na gruzach fortun szlacheckich, zwrócili się ku niej i nowemu słońcu bić czołem zaczęli. Atoli wówczas jeszcze, zgodna harmonja panowała między polską a semicką nacją. Żydostwo posługiwało się w stosunku z miejscową ludnością jedynie polskim językiem, który głuszył wszystkie inne narzecza» ${ }^{64}$.

У гэтым кантэксце цікава, як 3. Кавалеўская характарызуе паводзіны яўрэяў у параўнанні з татарамі падчас вайны 1812 г.: «Żydzi, wrogo ku francuzom usposobieni, zachowywali się biernie, ale tatarzy mińscy wyrazili swą solidarność z ogółem polskim» ${ }^{65}$. Дарэчы, культурная асіміляцыя мінскіх татараў і зліццё іх 3 «z ogółem polskim» выяўлялася, напрыклад, у арганізаваным 15 сакавіка 1818 г. мулой мінскіх татар Якубам Здановічам у мясцовай мячэці такога мерапрыемства, як «obchód pogrzebowy, poświęcony pamiątce Tadeusza Kościuszki». Сярод удзельнікаў цырымоніi былі афіцэры, ветэраны паўстання 1794 г., сярод іншых Юзаф і Эліяш Мурза-Юшынскія, якія ваявалі «pod znakami Kościuszki 1794 roku». Мула выступіў

\footnotetext{
${ }^{62}$ Z. Kowalewska, op. cit., s. 29.

${ }^{63}$ Ibidem, s. 37.

${ }^{64}$ Ibidem, s. 38.

${ }^{65}$ Ibidem, s. 12.
} 
Віктар Корбут, Ідэнтычнасць жыхароў Мінска ў XIX - пачатку XX ст... 149

3 прамовай на польскай мове «о zeszłym ś. p. Tadeuszu Kościuszce Naczelniku woysk polskich $»^{66}$.

Такім чынам, паводле 3. Кавалеўскай, польскую моўна-культурную групу насельніцтва складалі не толькі арыстакраты мясцовага паходжання, але і яўрэі і татары, якія інтэграваліся з польскамоўнай арыстакратыяй.

Абмяркоўваючы падзеі 1863 г., 3. Кавалеўская закранае таксама пытанне аб пазіцыі, якую займалі падчас Студзеньскага паўстання яўрэi: «Społeczeństwo żydowskie, z którem, jako z pewną siłą, ruch krajowy liczyć się musiał, wydało wprawdzie i wielu zdrajców, lecz więcej jeszcze elementów życzliwych, których usługi nader były cenne. Niejednokrotnie też żydzi [так у арыгінале. - B.K.] ratowali życie ginącym, wydostawali paszporty dla tych, którzy już ich dostać nie mogli, uprzedzali o niebezpieczeństwie, wynajdowali zaradcze środki». Пільнае да дэталей вока 3. Кавалеўскай адзначае, што яўрэі дзейнічалі не без выгады: «Zręczni i przebiegli, umieli dotrzeć tam, gdzie nikt inny dojść nie mógł. Znajdowali drogę do srogich urzędników, którzy już napływali do kraju ze wschodu i opanowując ich stopniowo, czynili z nich narzędzie do celów swoich» ${ }^{67}$. Гэта адбывалася ў ключавы момант для будучыні не толькі Мінска, але ўсёй Літвы і Беларусі: «Polacy i katolicy zewsząd już zaczęli być usuwani, a na ich miejsce na razie, w braku poważniejszego elementu prawosławnego, spływać tu zaczęli z Rosji różni ludzie, śpieszący do kraju, by w nim zrobić karjerę. Szlachetniejsze żywioły rosyjskie niechętnie jeszcze na Litwę zjeżdżały, ale różnych robigroszów, awanturników i rycerzy, szukających przygód, nie brakło. Żydzi, przewąchawszy wnet ich słabe strony, umieli z tego korzystać i załatwiać interesy i swoje i cudze» ${ }^{68}$. Урэшце, 3. Кавалеўская сцвярджае, што заняпад мясцовай арыстакратыі

${ }^{66}$ Opisanie obchodu żałobnego nabożeństwa za duszę ś. p. Tadeusza Kościuszki, odbytego w Mińsku dnia 7. Marca 1818. roku w kościele Katedralnym, Wilno 1818, s. 36-39.

${ }^{67}$ Z. Kowalewska, op. cit., s. 119.

${ }^{68}$ Ibidem, s. 119-120. 
ў выніку падзей 1863 г. выклікаў узмацненне яўрэйскага элемента. Гэты працэс мемуарыстцы бачыўся так: «Ten chaos, który po burzy kraj ogarnął, ta zawierucha, w której się znalazła własność ziemiańska ze wszystkimi dochodami swymi, opuszczona przymusowie przez wielu właścicieli, konfiskowana, sprzedawana gwałtownie, przerzucana jak piłka z rąk do rąk, które ją eksploatowały, były początkiem ruiny ekonomicznej i upadku dawnego znaczenia ziemiaństwa, a fundamentem kapitałów żydowskich i ich dzisiejszej finansowej siły. Na gruzach fortun ziemiańskich żydzi zbudowali swe fundusze» ${ }^{69}$.

\section{«Rosjanie zajmowali jedynie niemal stanowiska administracyjne»}

3. Кавалеўскай Мінск 1830-х гг. бачыўся як горад у Літве, у складзе расійскай дзяржавы, дзе вадзіла рэй польская арыстакратыя. Пры гэтым расійская ўлада таго часу не апісваецца як рэпрэсіўная: «Rok 1831 nie zrobił w Mińszczyźnie szczerb wielkich... Szeregi ziemiańskie prawie nie nadwerężone, pełne jeszcze były siły, potęgi i blasku. [...] A że szlachta cieszyła się podówczas protekcją Monarszą w całem Państwie, więc i ziemiaństwo polskie, korzystając z wielu przywilejów swego stanu, rej wodziło w kraju» ${ }^{70}$. Сярод жыхароў цэнтра Мінска таго часу - Высокага Рынку 3. Кавалеўская «заўважае» i рускіх: «kupcy i handlarze ruscy, jak Rogow, Paluszkin, Diechtierow i t. d. Naprzeciw zaś, w kamienicy, stojącej oddzielnie na placyku za Ratuszem, błyszczały najwspanialsze podówczas sklepy żydowskie» ${ }^{71}$.

Апрача рускіх купцоў 3. Кавалеўская адзначае яшчэ адну групу рускага насельніцтва Мінска ў перыяд да 1863 г.: «Oprócz zamożnego ziemiaństwa, błyszczącego na powierzchni społecznej, tuliło się też w Mińsku sporo drobnej, ubogiej szlachty, niższe urzędy i posady

\footnotetext{
${ }^{69}$ Ibidem, s. 120.

${ }^{70}$ Ibidem, s. 25.

${ }^{71}$ Ibidem, s. 26.
} 
zajmującej. Wszystkie instytucje, od góry do dołu, pełne były swojskiego elementu. Rosjanie zajmowali jedynie niemal stanowiska administracyjne, pozostawiając wszelkie inne dla miejscowego żywiołu» ${ }^{72}$.

Трэба адзначыць, што ў польскамоўным арыстакратычным соцыуме Мінска існавала апазіцыя польскі - рускі, але не польскі беларускі. Як заўважае 3. Кавалеўская, у 1856 г. «ogól polski był podówczas jeszcze bardzo czuły na wszelkie grzechy religijno-narodowe i karał je słusznym ostracyzmem. Oburzył się więc ponownie, gdy córka Placyda Jankowskiego, syna wprawdzie parocha unickiego, ale uchodzącego za polaka [так у арыгінале. - B.K.] i piszącego utwory powieściowe po polsku, poślubiła nauczyciela gimnazjum, Wasiljewa, tworząc małżeństwo mieszane» ${ }^{73}$.

Такім чынам, паводле 3. Кавалеўскай, у Мінску рускі элемент прысутнічаў сярод купцоў і чыноўнікаў, але, у адрозненне ад яўрэяў і татар, не быў схільны да зліцця з мясцовым польскім элементам.

Тыя пераўтварэнні, якія адбыліся ў горадзе ў наступныя дзесяцігоддзі, можна сказаць, шакіравалі Я. Булгака, які ў ліпені 1911 г. наведаў горад: «Mińsk poznałem dopiero jako człowiek dorosły, więc nie miałem z nim żadnych zrostów uczuciowych z dzieciństwa, a jego zdziczały rosyjsko-żydowski wygląd i wybitne odpolszczenie nie mogły mnie usposobić do niego przychylnie» ${ }^{74}$.

\section{«W życiu mi się ani śniło bym, urosłszy wsrzód Litwinów, pokochał Białorusinów»}

У XIX ст. беларуская мова ў Мінску, трэба меркаваць з мемуараў, функцыянавала толькі як сродак камунікацыі прыезджых сялян.

Першыя праявы беларускай культурнай актыўнасці ў Мінску трэба адносіць да 1852-1856 гг. Гэта звязана перш за ўсё з творчасцю В. Дуніна-Марцінкевіча.

${ }^{72}$ Ibidem, s. 37.

${ }^{73}$ Ibidem, s. 66.

${ }^{74}$ J. Bułhak, op. cit., s. 32. 
Як успамінала Зоф’я Кавалеўская, «istniał wówczas w Mińsku teatr polski, licznie uczęszczany, acz repertuar jego nie był zbyt bogaty, ani też zbyt wielkie siły artystyczne. Teatr miał jednak powodzenie znaczne. Mieścił się na Wysokim-Rynku w wynajętej kamienicy» ${ }^{75}$. 23 і 24 верасня 1841 г. тут адбылася прэм’ера аперэты «Рэкруцкі жыдоўскі набор» (лібрэта В. Дуніна-Марцінкевіча, музыка С. Манюшкі і Канстанты Кшыжаноўскага) ${ }^{76} .9$ лютага 1852 г. тут была пастаўлена опера «Sielanka» на лібрэта В. Дуніна-Марцінкевіча i музыку С. Манюшкі і К. Кшыжаноўскага ${ }^{77}$. Вядомы частковы змест афішы да спектакля: «Опера въ двухъ дъйствіяхъ на польскомъ и простонародномъ языкъ сочиненія Викентія Марцинкевича съ музыкою Монюшки, Кржижановскаго и прочихъ под заглавіемъ «Селянка» ${ }^{78}$. Гэта былі прэцэдэнты ў гарадской культуры, калі на сцэне тэатра бадай упершыню гучала беларуская мова (прынамсі, пра ранейшыя прыклады выкарыстання гэтай мовы на мінскай сцэне невядома).

Друкар Ёкель Двожац (Jokiel Dworzec) і мінскія кнігары браты Бейліны (bracia Bejlinowie) у 1855-1856 гг. выдалі тры кнігі з творамі на беларускай і польскай мове Вінцэнта Дуніна-Марцінкевіча ${ }^{79}$.

3. Кавалеўская і Т. Корзан, аднак, пра творчасць В. Дуніна-Марцінкевіча не ўспамінаюць. Ці значыць гэта, што дзейнасць пісьменніка не запала ў памяць мінчанам? Вось як сам В. Дунін-Марцін-

${ }^{75}$ Z. Kowalewska, op. cit., s. 83.

${ }^{76}$ В. Н. Денисов, ор. cit., с. 70; Т. А. Карповіч, Культурнае жыциё Мінска I паловы XIX ст., Мінск 2007, с. 22.

${ }^{77}$ В. Н. Денисов, оp. cit., с. 68-69; У. Дзянісаў, Гісторыя аднаго будынка, «Помнікі гісторыі і культуры Беларусі» 1985, № 5, с. 30. Тэкст «Sielanki» быy̆ апублікаваны ў Вільні асобным выданнем яшчэ ў 1846 г.: W. Dunin Marcinkiewicz, Sielanka. Opera we dwóch aktach, Wilno 1846.

${ }^{78}$ У. Дзянісаў, 3 гісторыі тэатральных будынкаў XIX cm. у Мінску, «Тэатральны Мінск» 1985, № 3, с. 40.

${ }^{79}$ A. Jelski, op. cit., s. 455; W. Dunin Marcinkiewicz, Hapon, powieść białoruska, $z$ prawdziwego zdarzenia $w$ języku białoruskiego ludu napisana, Mińsk 1855; Idem, Wieczernice i Obłakany. Poezye, Mińsk 1855; Idem, Ciekawyś? Przeczytaj! Trzy powiastki i wierszyk ulotny, Mińsk 1856. 
кевіч пісаў пра мэты і вынікі сваёй творчай актыўнасці: «Żyjąc śród ludu, mówiącego białoruskim narzeczem, wcielony w jego sposób myślenia, marząc o doli tego szczepu bratniego, w niemowlęctwie i ciemnocie odrętwiałego, postanowiłem, dla zachęty go do oświaty, w duchu jego zwyczajów, podań i zdolności umysłowych, pisać we własnym jego narzeczu [...]. [...]

Ten mój pomysł i dążności, pojęte i ocenione zostały w Królestwie, nie pojętemi na Litwie» ${ }^{80}$.

В. Дунін-Марцінкевіч яшчэ не разглядаў сваю дзейнасць у кірунку эмансіпацыі беларускіх сялян ад польскіх паноў і фарміравання беларускай нацыянальнай ідэнтычнасці. Наадварот, для яго гэта была творчасць 3 мэтай сацыяльнага збліжэння сялян і паноў у рамках адной польскай нацыянальнай супольнасці. Пра гэта ён пісаў Яну Карловічу ў 1868 г., тлумачачы, чаму «gorliwie zajął się uprawą ludowej niwy»: «Bracia młodsi jednej i tej że matki [...] silniej w ostatnich czasach poczęli okazywać do starszej swej braci zakorzeniałą oddawna już w sercach swych nienawiść, jakową ludzi złej woli, korzystając z jej ciemnoty, fałszywemi podszepty starali się więcej ją rozdmuchiwać, jedyny środek zbliżenia ku sobie tych dwóch, przeciwnych, żywiołów upatrywałem w oświacie pierwszych». Такім чынам, В. Дунін-Марцінкевіч ставіў асветныя мэты, спадзеючыся знізіць градус сацыяльнага антаганізму. Адначасова ён разлічваў на тое, што сялян пасля прачытання «powiastek z ich domowego zycia» зацікавіць польская літаратура: «Dla tego jedynie drukowałem takowe polskimi literami, [...] aby ciemny kmiotek, rozciekawiony podaniami, własnem jego narzeczem, rozrobionemi, z ochotą ucząc się polskich liter, aby mógł czytać ustępy z własnego życia uczył się razem i polskiej, macierzystej literatury» ${ }^{81}$. Такім чынам, для В. Дуніна-Марцінкевіча яго беларускамоўныя творы быццам бы толькі прыступка, якую ён

${ }^{80}$ В. Дунін-Марцінкевіч, Збор твораў. $У 2$ m. Т. 2. Вершаваныя аповесці i апавяданні, вершы, публіцыстыка, лісты і пасланні, пераклады, Dubia, уклад. Я. Янушкевіч, Мінск 2008, с. 391-392.

${ }^{81}$ Ibidem, c. 416-417. 
падстаўляе беларускаму селяніну, каб той падняўся на адзін узровень - да «polskiej, macierzystej literatury». Разуменне гэтага аспекта дазваляе ўспрымаць дзейнасць В. Дуніна-Марцінкевіча ў такім фармаце, што старэйшы брат (паляк, шляхціц) вучыць малодшага (беларуса, селяніна).

Пры гэтым сам В. Дунін-Марцінкевіч яшчэ ўсведамляў сябе і літоўцам, прызнаючыся ў вершы «Do poczciwych Białorusinów»:

W życiu mi się ani śniło

Bym, urostszy wsrzód Litwinów,

Pokochat Białorusinów ${ }^{82}$.

Як ужо адзначаў Рышард Радзік, «роeta łączył swą polskość - polityczno-narodową, choć także językowo-kulturową, stanową i domową zarazem, w której wyrósł - $\mathrm{z}$ regionalną, terminologicznie pierwotnie litewską, lecz jakże bliską mu kulturowo ludową białoruszczyzną» ${ }^{83}$. Можна дапусціць, што падобную свядомасць мелі ўсе ў Мінску, хто так ці інакш быў блізкі па поглядах В. Дуніну-Марцінкевічу.

Tое, што В. Дунін-Марцінкевіч добра разумеў прыроду ўзаемаадносін паміж беларускімі сялянамі і польскімі панамі і крызіс, які наступіў у 1863 г., не выклікае сумненняў. 3. Кавалеўская ў сваіх запісках паказвае, як у падзеях 1863 г. адлюстраваўся сацыяльны разлом у мясцовым соцыуме: «Dnia 7 marca opublikowano w Mińsku Ukaz z dn. 19 lutego o zniesieniu pańszczyzny i uwłaszczeniu włościan. Odczytywano go w kościołach i cerkwiach, gdzie duchowieństwo prawosławne, jak mówiono, uzupełniało go wielu komentarzami, rozbudzającymi nieraz wśród ludu wrogie instynkta ku swym byłym panom» ${ }^{84}$. 3. Кавалеўская апісвае падзеі 1863 г. як сапраўдную рэвалюцыю, якая стала катастрофай для палякаў: «Nagły ten przewrót ekonomiczno-społeczny przeraził cały poważniejszy ogół polski.

${ }^{82}$ Ibidem, c. 381.

${ }^{83}$ R. Radzik, Między zbiorowościa etniczna a wspólnotą narodowa. Białorusini na tle przemian narodowych w Europie Środkowo-Wschodniej XIX st., Lublin 2000, s. 222.

${ }^{84}$ Z. Kowalewska, op. cit., s. 102. 
Każda chwila przełomowa, nawet w kulturalnych społeczeństwach i normalnych warunkach, rodzi chaos i powikłania. U nas, w wyjątkowej sytuacji, w tak naprężonym momencie, nagłe rozkiełzanie ciemnego a przywykłego do cugli - elementu, mogło wywołać groźne następstwa. Dobrej tylko i łagodnej naturze białorusinów [так у арыгінале. - B.K.] i pewnemu ich jeszcze przywiązaniu do ziemiaństwa zawdzięczać należy, iż w czasie miotającej burzy w kraju nie powtórzyły się tu krwawe galicyjskie sceny. Albowiem choć gorsze żywioły dopuszczały się pewnych ekscesów, ogół zachowywał się niemal biernie, a pewna część jego szczerą życzliwość i pomoc powstaniu okazywała» ${ }^{85}$. Пaводле 3. Кавалеўскай, як і паводле В. Дуніна-Марцінкевіча, апазіцыя палякі - беларусы мела шансы на ўзнікненне, але толькі са знешняй дапамогай з боку рускіх. Аднак тое, што падставай для магчымага супрацьстаяння былі не нацыянальныя, а сацыяльныя прычыны, 3. Кавалеўская выразна ўсведамляе і падкрэслівае. 3. Кавалеўская заўважае, што якраз у гэты час расійскія ўлады выкарыстоўвалі мясцовае сялянства ў барацьбе з польскай арыстакратыяй: «Z włościan utworzona została tak zwana milicja, dopomagająca do łapania powstańców i trzymająca straż u rogatek, któremi zamykały się nie tylko miasta i miasteczka, lecz i wsie nawet i przejazdy wszelkie. Nikt się bez paszportu ruszyć z domu nie mógł. Przy rogatkach bowiem podróżnych zatrzymywali włościanie, domagając się «praszportu». [...] Duma pańska wystawioną nieraz bywała na ciężkie próby... [...] Ciemne, nizkie instynkta, korzystając $\mathrm{z}$ danego sobie prawa, mściły się za dawne urazy» ${ }^{86}$. I хаця 3. Кавалеўская ў гэтым выпадку не разглядае канфлікту сялян і паноў у нацыянальных колерах, аднак 3 кантэксту зразумела, што перадумовы для фарміравання такой апазіцыі існавалі, хаця не без выключэнняў на карысць супрацоўніцтва паноў (палякаў) і сялян (беларусаў): «Bywały jednak i takie wypadki, iż włościanie, poznając dawnych swych panów, w fałszywy

\footnotetext{
${ }^{85}$ Ibidem, s. 103.

${ }^{86}$ Ibidem, s. 118.
} 
zaopatrzonych paszport, sami im ułatwiali ucieczkę. W organizmie włościańskim, w owych przejściowych chwilach, toczyła się ciągle bezwiedna walka złych i mściwych instynktów, rozdmuchiwanych przez niektórych urzędników świeckich i duchownych w celach politycznych, $\mathrm{z}$ dobrymi i łagodnymi pierwiastkami, leżącymi w naturze i charakterze białorusinów [так у арыгінале. - B.K.] $\gg^{87}$.

Аднак, як піша У. Ігнатоўскі, «што датычыць Меншчыны, дык трэба зазначыць, што сялянства ў большасці сваёй не спачувала паўстанцам. Дзякуючы значнаму ўдзелу ў паўстанні мясцовых паноў, сяляне былі проці паўстанцаў, бачачы ў іх асобе толькі паноў. $[\ldots]$

Выключэннем з'яўляюцца тыя мясцовасці ў Віленскай, Горадзенскай і Ковенскай губернях, дзе дзейнічалі крайнія чырвоныя, як В. Урублеўскі, К. Каліноўскі, А. Мацкевіч і іншыя, якія апору паўстання бачылі не ў шляхце, а ў сялянах і стаялі на прынцыпе аддачы панскай зямлі сялянам. Ва ўсходніх губернях Беларусі - Biцебскай, Менскай і Магілёўскай пераважаюць адмоўныя адносіны сялянства да паўстання. Наогул сацыяльная процілегласць паміж селянінам і панам адчувалася на кожным кроку на ўсёй тэрыторыі Беларусі ${ }^{88}$.

Паводле У. Ігнатоўскага, віленскі генерал-губернатар Міхаіл Мураўёў, душыцель паўстання, «імкнуўся ўсімі сіламі ўлажыць у сялянскія галовы думку, што паўстанцы складаюцца выключна 3 паноў, што гэтыя паны сваім паўстаннем шкодзяць інтарэсам сялянства; ён выкарыстоўваў процілегласць сацыяльных інтарэсаў сялян і паноў для таго, каб перацягнуць сялянства на час паўстання ў бок расійскага ўрада». М. Мураўёў усведамляў, што «вся сила, на которую может опираться здесь правительство, заключается в одном сельском населении, и потому для самой пользы государства разъединение его с прочими враждебными правительству сослови-

\footnotetext{
${ }^{87}$ Ibidem, s. 119.

${ }^{88}$ У. Ігнатоўскі, op. cit., с. 562, 566.
} 
Віктар Корбут, Ідэнтычнасць жыхароў Мінска ў XIX - пачатку XX ст... 157

ями, особенно землевладельцами польского происхождения, необходимо» ${ }^{89}$.

У той час «беларускай альтэрнатывы» не існавала. Да 1861 г. беларусы - гэта прыгонныя сяляне, нават без усякіх намёкаў на нацыянальную свядомасць. Беларусы былі не суб'ектам, а аб'ектам гісторыі. А польская арыстакратыя ў Беларусі была мясцовая, мясцовым суб'ектам, якога, аднак, расійская ўлада звяла да ролі аб'екта. І таму паўстанне 1863 г., будучы польскім, з'яўлялася і мясцовым - беларускім у тэрытарыяльным сэнсе, але не ў нацыянальным. Гэта было змаганне за тое, каб вярнуць сабе ў сябе дома правы суб'екта гісторыі. I гэтыя тонкасці трэба разумець, інтэрпрэтуючы тыя падзеі сёння. У тым жа сэнсе трэба разумець і нацыянальную, а дакладней, нацыянальна-сацыяльную, часам нацыянальна-сацыяльна-рэлігійную ідэнтычнасць людзей таго часу (паляк, «пан» (арыстакрат), католік vs. рускі, «мужык» (селянін), праваслаўны).

Вышэйпрыведзеныя сведчанні пра Мінск XIX - пачатку XX ст. амаль не фіксуюць прысутнасці ў горадзе беларускага элемента. Гэта можна патлумачыць тым, што гэты элемент быў пераважна вясковы, негарадскі. Гэта пацвярджаюць і ўспаміны Т. Корзана пра перыяд вучобы ў Мінскай мужчынскай гімназіі (першая палова 1850-х гг.): «Ucho moje było już oswojone z mową bialoruską pospólstwa wiejskiego i wieśniaków, przywożących do miasta produkty żywności lub drzewo opałowe: łatwiej tedy, niż ucho Mazura, przyswajało dźwięki wielkorosyjskie» ${ }^{90}$.

Увогуле, трэба сказаць, што беларусы былі супольнасцю, існаванне якой было відавочнае для старонняга назіральніка, у той жа час самі яны не мелі нацыянальнай самасвядомасці, калектыўнай памяці. Аднак менавіта факт існавання беларускай мовы і асобнай сацыяльнай групы, якая ёю карысталася, прымушала і польскіх і рускіх ідэолагаў выкарыстоўваць гэту мову для сваёй прапаганды,

\footnotetext{
${ }^{89}$ Ibidem, c. $586-587$.

${ }^{90}$ T. Korzon, op. cit., s. 24.
} 
што ў пэўным сэнсе можна аднесці і да творчасці таго ж В. Дуніна-Марцінкевіча. Праўда, як адзначае У. Ігнатоўскі, «беларуская мова і культура [пасля 1863 г. - B.K.] таксама падпалі пад забарону, бо, па-першае, яны лічыліся «мужыцкімі», што зводзіла іх, як культурныя каштоўнасці, да нуля, па-другое, яны лічыліся польскімі, калі апраналіся ў форму лацінкі» ${ }^{91}$.

Наступныя, пасля дзейнасці В. Дуніна-Марцінкевіча, праявы беларускай грамадскай актыўнасці ў Мінску трэба адносіць да канца 1880 - 1890-х гг. 3. Кавалеўская ўзгадвае пра Яна Неслухоўскага (Янку Лучыну): «Do bardzo znanych, zrosłych niemal z miastem, należały domy Śliźniów i Niesłuchowskich. Juljan Niesłuchowski był prezesem Izby Cywilnej. Jeden zaś z jego synów, Jan, zasłynął następnie, jako lirnik miejscowy» ${ }^{92}$. Трэба падкрэсліць, што 3. Кавалеўская пры гэтым не адзначае, што Я. Неслухоўскі пісаў як па-польску, так і па-беларуску і па-руску. У 1886 г. у Мінску пачала выходзіць на рускай мове грамадска-літаратурная газета «Минский листок». На яе старонках, $з$ першага нумара, друкаваліся вершы Я. Неслухоўскага. У выданні таксама публікавалася паэма на беларускай мове «Тарас на Парнасе» (1889 г.), творы іншых мясцовых літаратараў К. Каганца, Д. Бохана і інш., этнаграфічныя нарысы пра беларусаў М. Янчука, Я. Ляцкага, А. Слупскага, М. Доўнар-Запольскага, водгукі на працы Е. Раманава, П. Шэйна, Я. Карскага. За публікацыю матэрыялаў на беларускай мове газета атрымлівала заўвагі з цэнзурнага ведамства. У канцы 1902 г. «Минский листок» стаў выходзіць пад назвай «Северо-Западный край». Газета аднавіла літаратурныя традыцыі, страчаныя «Минским листком» у канцы 1890-х гадоў93. У 1905 г. на яе старонках з'явіўся верш Яна Луцэвіча (Янкі Купалы) «Мужык». Гэта быў першы твор паэта, апублікаваны на

${ }^{91}$ У. Ігнатоўскі, op. cit., c. 601; больш падрабязна гл.: D. Staliūnas, Rusinimas: Lietuva ir Baltarusija po 1863 m., Vilnius 2009; А. Цьвікевіч, «Западно-руссизм». Нарысы з грамадзкай мысьлі на Беларусі у ХІХ і пачатку ХХ в., Мінск 1993.

${ }^{92}$ Z. Kowalewska, op. cit., s. 35.

93 3. В. Шибеко, op. cit., c. 188, 190. 
беларускай мове. Да гэтага Я. Луцэвіч пісаў па-польску, прычым, як ён успамінаў, па-беларуску пачаў пісаць у т. л. пад уплывам творчасці В. Дуніна-Марцінкевіча на гэтай мове ${ }^{94}$.

У канцы XIX ст. некаторыя польскія шляхціцы прымалі беларускую ідэнтычнасць. Адным з іх быў мастак і пісьменнік Казімір Кастравіцкі (Карусь Каганец). Ён скончыў мінскае гарадское вучылішча, у пошуках заробку бадзяўся па ўсёй Беларусі. Але вяртаўся ў Мінск. Насіў сялянскую вопратку з чырвоным поясам. Вучнямі К. Каганца былі браты Ян (Іван) і Антоні (Антон) Луцкевічы, якія вучыліся ў канцы 1890-х гг. у Мінскай мужчынскай гімназіi. Пісьменнік прыходзіў да іх на пасяджэнні вучнёўскага гуртка, чытаў свае вершы, вёў гутаркі. Сустракаўся з К. Кастравіцкім і будучы выдатны беларускі дзеяч Аляксандр Уласаў. Менавіта Я. і А. Луцкевічы, А. Уласаў у пачатку 1900-х гг. стаялі ля вытокаў сучаснага беларускага нацыянальнага руху. А. Уласаў сярод тых, хто паўплываў на фарміраванне яго поглядаў, называў таксама мінскага калекцыянера Хэнрыка Татура ${ }^{95}$. Аднак, як адзначае Захар Шыбека, «будучи центром белорусского национального рынка, Минск не стал в конце XIX - начале XX века центром белорусского национально-культурного возрождения, уступив эту роль Вильно. Позиции русификаторов были в нем особенно сильны. Даже польская и еврейская культуры, имевшие в других городах прочные традиции и сохранявшие преемственность, существовали в виде небольших очагов $)^{96}$.

У пачатку 1907 г. ураджэнец Мінска, артыст польскай сцэны Фларыян Ждановіч дэкламаваў на арганізаваных у горадзе дабрачынных вечарах беларускія вершы. Крыху пазней з групай таварышаў ён падрыхтаваў і паказаў у садзе польскага спартыўнага таварыства «Сокал» праграму «Беларускі кірмаш», якая ўключала

${ }^{94}$ Я. Купала, Поўны збор творай. У 9 m. Т. 9. Кн. 2. Дапаўненні да папярэдніх тамоў, Мінск 2003, с. 58.

95 3. В. Шибеко, оp. cit., с. 84.

${ }^{96}$ Ibidem, c. 228. 
беларускія вершы і песні, за што атрымаў вымову ад адміністрацыі «Сокала» і папярэджанне ад памочніка паліцмайстра ${ }^{97}$.

Такім чынам, к пачатку XX ст. адбылася значная трансфармацыя ў культурнай прасторы Мінска. Руская культура стала пануючай, у той час як польская адышла на другі план, а беларуская не змагла скласці ім канкурэнцыю, бо знаходзілася ў зародкавай стадыі, калі гаварыць пра гарадскую, нацыянальную культуру.

У 1897 г. удзельная вага беларусаў у насельніцтве Мінска складала 8,98\%, а ў верасні 1917 г. - 2,37\% ад цывільнага насельніцтва, а ад усяго насельніцтва - 1,12\% (падчас Першай сусветнай вайны Мінск з'яўляўся адным з галоўных цэнтраў тылу расійскага войска і ў розных вайсковых часцях і арганізацыях горада налічвалася каля 159 тыс. салдат). Такім чынам, «колькасць патэнцыяльных прыхільнікаў беларускага дзяржаўнага самавызначэння была надзвычай мізэрнай» ${ }^{98}$.

Можна назіраць кардынальную змену, якая адбылася ў Мінску з 1863 да 1917 г. Калі раней нават яўрэі лічылі патрэбным ведаць польскую мову, то цяпер месца прэстыжнай і абавязковай заняла руская. Як успамінаў Мікалай Улашчык, у 1917 г. Мінск бачыўся яму і яго аднавяскоўцам з ваколіц Койданава так: «У Менску жывуць толькі паны, мужыкоў, людзей простых там няма, і таму трэба, калі збіраешся жыць у Менску, самому імкнуцца ў паны - г. зн. найперш гаварыць па-руску, каб менскія паны не смяяліся» ${ }^{99}$. М. Улашчык адзначаў, што, паводле ўяўленняў яго аднавяскоўцаў, сярод якіх былі і праваслаўныя (саманазва «рускія»), і католікі (саманазва «палякі»), «прыроджанаю натуральнаю моваю кожнага чалавека была мова простая, а ўжо пасля, з ростам, калі чалавек удаснальваўся, ён

${ }^{97}$ Ibidem, c. 173 .

${ }^{98}$ А. А. Каваленя, В. В. Даніловіч, В. Г. Мазец, С. А. Траццяк, Беларуская Народная Рэспубліка - крок да незалежнасці. Да 100-годдзя абвяшчэння. Гістарычны нарыс, Мінск 2018, с. 13-14.

${ }_{99}^{9}$ М. Улашчык, Дацьь народу гісторыю. Усnаміны, лісты, укл. А. Каўка, М. Скобла; навук.-рэд. рада: В. Голубеў [і інш.], Мінск 2016, с. 125. 
Віктар Корбут, Ідэнтычнасць жыхароў Мінска ў XIX - пачатку XX ст.... 161

вучыўся гаварыць ці па-руску («хораша»), ці па-польску («далікатна»)» ${ }^{100}$. Гэтыя факты ідэнтычнасці сялян 3-пад Мінска вельмі важныя для разумення таго, як беларуская мова і беларускі народ успрымаліся мінчанамі. Але яшчэ больш цікава, як успрымалі беларускіх сялян пад Мінскам рускія салдаты падчас Першай сусветнай вайны, паводле сведчання М. Улашчыка: «Вы кто? - у мацеры пытаюцца. «Мы рускія», - адказвае. «Какие вы русские! Вы - поляки!» - і на ікону ўніяцкую, на куце, паказваюць» ${ }^{101}$.

Магчыма, што выкарыстанне прадстаўнікамі польскамоўнага насельніцтва Мінска формы назвы горада Mińsk Litewski паўплывала на рашэнне стваральнікаў беларускай дзяржаўнасці - Беларускай Народнай Рэспублікі ў 1918 г. падкрэсліць беларускасць горада. Так, першая «Устаўная грамата да народаў Беларусі» Выканаўчага камітэта Савета Усебеларускага з'езда была выдадзена 21 лютага 1918 г. у «Менску-Беларускім». У абвестках Народнага Сакратарыята Беларусі № 1 і 3 (за 21 і 23 лютага 1918 г.) горад называецца «Мінск-Беларускі». Другая «Устаўная грамата да народаў Беларусі» Выканаўчага камітэта Савета Усебеларускага з'езда была выдадзена 9 сакавіка 1918 г. у «Мінску Беларускім». Трэцяя «Устаўная грамата да народаў Беларусі» Рады БНР «дана у Менску-Беларускім» 25 сакавіка 1918 г. Пастанова НС БНР ад 27 сакавіка была выдадзена ў «Мінску Беларускім». У абвестцы НС БНР ад 19 красавіка фігуруе «гор. Мінск-Беларускі». 3 красавіка ў беларускамоўным справаводстве БНР панавала ўжо форма «Менск» ${ }^{102}$, без дадатку «Беларускі», хаця і з'яўлялася яшчэ форма «Мінск» - напрыклад, на бланку рэдакцыі газеты «Беларускі шлях» 25 ліпеня 1918 г. ${ }^{103}$

${ }^{100}$ Ibidem, c. 226.

${ }^{101}$ Ibidem, c. 331.

${ }^{102}$ Архівы Беларускай Народнай Рэспублікі. Т. 1. Кн. 1. Фонд № 582 Дзяржаўнага Архіву Літвы («Рада Міністраў Беларускай Народнай Рэспублікі»), укл. С. Шупа, Vilnius, New York, Мінск, Praha 1998, с. 47-49, 53, 63, 66, 73, 78, 87, 107, 125, 136, 147, 160, 181, 226, 237, 276, 285, 286, 291, 303, 308, 309.

${ }^{103}$ Ibidem, c. 215. 
Варта таксама адзначыць, што пасля стварэння формы беларускай дзяржаўнасці на савецкай аснове з цэнтрам у Менску і ажыццяўлення ў другой палове 1920-х гг. беларусізацыі многія праявы польскай культуры ў Мінску XIX - пачатку XX ст. інтэрпрэтаваліся як беларускія. У гэты час бадай усё тое, што мела мясцовае паходжанне, успрымалася як «беларускае». Таму няма нічога дзіўнага, што Ф. Рушчыц, які правёў дзяцінства і юнацтва ў Мінску, вырас у гэтым горадзе, жывучы ў Вільні, 5 студзеня 1929 г. запісаў у дзённіку: «Na Szubrawii mówiono o Kownie, także o Mińsku, dokąd jeździł po archiwalia Weytko z Archiwum Państwowego Wileńskiego. W katalogu muzeum figuruję podobno razem z Rustemem, Siemiradzkim i Siestrzeńcewiczem jako malarz białoruski. Zapewne są tam moje «Dożynki» ${ }^{104}$.

Мінскія палякі ў большасці не прынялі ні рускай, ні беларускай ідэнтычнасці. Аднак ужо з часоў В. Дуніна-Марцінкевіча назіралася сярод некаторых 3 іх схільнасць да паразумення горада 3 вёскай - палякаў з беларусамі. Аднак сацыяльныя трансфармацыі, якія адбыліся пасля 1863 і асабліва пасля 1917 г. вельмі імкліва змянілі выгляд Мінска, які з польска-яўрэйскага стаў руска-яўрэйскім горадам, і пазіцы рускай культуры ў ім сталі пануючымі і застаюцца такімі да нашых дзён. Прычым русіфікацыя закранула і мясцовых палякаў (тых, што не выехалі ў Польшчу), і беларусаў. А ў выніку сацыяльных трансфармацый пасля 1917 г. сацыяльны падзел, які існаваў паміж палякамі-гараджанамі і беларусамі-сялянамі, цалкам знік. Больш падрабязна ўмовы развіцця польскай мовы і культуры ў Мінску ў даваенны савецкі перыяд разгледжаны ў працы Мікалая Іванова ${ }^{105} .3$ канца 1930-х да канца 1980-х гг. у Мінску не існавала ніякіх форм польскай культурнай і грамадска-палітычнай дзейнасці.

${ }^{104}$ F. Ruszczyc, Dziennik. Cz. 2. W Wilnie. 1919-1932, wybór, układ, oprac., wstęp i posłowie E. Ruszczyc, Warszawa 1996, s. 460.

${ }^{105}$ M. Iwanow, Pierwszy naród ukarany. Polacy w Związku Radzieckim. 19211939, Warszawa, Wrocław 1991. 
Віктар Корбут, Ідэнтычнасць жыхароў Мінска ў XIX - пачатку XX ст... 163

Успаміны жыхароў Мінска - вельмі каштоўная крыніца для пазнання гісторыі горада. Асаблівая іх каштоўнасць у тым, што яны паказваюць жыццё горада знутры, з усімі яго супярэчнасцямі. Жыхары Мінска, якія лічылі сябе палякамі, да 1863 г. складалі вельмі значную частку яго жыхароў, уплывалі на жыццё горада, гэтыя пазіцыі яны захоўвалі, хаця і ў меншай ступені, і пазней - да 1917 г.

\section{Літаратура}

Arkhivy Byelaruskay Narodnay Respubliki. T. 1. Kn. 1. Fond № 582 Dzyarzhawnaha Arkhivu Litvy ("Rada Ministrau Byelaruskay Narodnay Respubliki»), ukl. S. Shupa, Vilnius, New York, Minsk, Praha 1998 [Архівы Беларускай Народнай Рэспублікі. Т. 1. Кн. 1. Фонд № 582 Дзяржсаўнага Архіву Літвы («Рада Міністрай Беларускай Народнай Рэспублікі»), укл. С. Шупа, Вільня, Нью-Ёрк, Менск, Прага 1998].

Bogdanovich A. Ye., Ya vsyu zhizn'stremilsya k svetu. V 2 kn. Kn. 1. Moi vospominaniya, sost. A. Vashchenko, Minsk 2012 [Богданович A.Е., Я всю жизнь стремился к свету. В 2 кн. Кн. 1. Мои воспоминания, сост. А. Ващенко, Минск 2012].

Bułhak J., Dwadzieścia sześć lat z Ruszczycem, Wilno 1939.

Denisov V. N., Ploshchad' Svobody v Minske, Minsk 1985 [Денисов В.Н., Площадь Свободы в Минске, Минск 1985].

Drozd Z., Tayamnitsy Dunina-Martsinkyevicha, Vilnius 2018 [Дрозд 3., Таямніцы Дуніна-Мариінкевіча, Вільнюс 2018].

Dunin Marcinkiewicz W., Ciekawyś? Przeczytaj! Trzy powiastki i wierszyk ulotny, Mińsk 1856.

Dunin Marcinkiewicz W., Hapon, powieść białoruska, z prawdziwego zdarzenia w języku białoruskiego ludu napisana, Mińsk 1855.

Dunin Marcinkiewicz W., Sielanka. Opera we dwóch aktach, Wilno 1846.

Dunin Marcinkiewicz W., Wieczernice i Obłakany. Poezye, Mińsk 1855.

Dunin-Martsinkyevich V., Zbor tvoraw. U 2 t. T. 1-2, ukl. Ya. Yanushkyevich, Minsk 2007-2008 [Дунін-Марцінкевіч В., Збор твораў. У 2 т. Т. 1-2, укл. Я. Янушкевіч, Мінск 2007-2008].

Dzyanisau U., Historyya adnaho budynka, «Pomniki historyi i kul'tury Byelarusi» 1985, № 5 [Дзянісаў У., Гісторыя аднаго будынка, «Помнікі гісторыі і культуры Беларусі» 1985, № 5]. 
Dzyanisau U., Z historyi teatral'nykh budynkaw XIX st. u Minsku, «Teatral'ny Minsk» 1985, № 3 [Дзянісаў У., 3 гісторыі тэатральных будынкаў XIX cm. у Мінску, «Тэатральны Мінск» 1985, № 3].

Firynovich A.E., Materyyaly fondu «Minskaha pavyatovaha suda» Natsyyanal'naha histarychnaha arkhiva Byelarusi ab padzyeyakh u Minsku napyaredadni pawstannya 1863-1864 hh. [u] Minsk i minchanye... [Фірыновіч А.Э., Матэрыялы фонду «Мінскага павятовага суда» Начьянальнага гістарычнага архіва Беларусі аб падзеях у Мінску напярэдадні паўстання 1863-1864 г2. [у] Мінск і мінчане...].

Ihnatowski U., 1863 hod na Byelarusi [u:] Ihnatowski U., Vybranaye, ukl. H. Zapartyka, navuk. red. I. Savyerchanka, Minsk 2018 [Ігнатоўскі У., 1863 год на Беларусі [у:] Ігнатоўскі У., Выбранае, укл. Г. Запартыка, навук. рэд. I. Саверчанка, Мінск 2018].

Iwanow M., Pierwszy naród ukarany. Polacy w Związku Radzieckim. 1921-1939, Warszawa, Wrocław 1991.

Jelski A., Mińsk [w:] Stownik geograficzny Królestwa Polskiego i innych krajów słowiańskich. T. VI, red. F. Sulimierski, B. Chlebowski, W. Walewski, Warszawa 1885.

Karpovich T. A., Kul'turnaye zhytstsyo Minska I palovy XIX st., Minsk 2007 [Карповіч Т.А., Культурнае жыщчиё Мінска I паловы XIX cm., Мінск 2007].

Katalitskiya svyatyni. Minska-mahilyowskaya arkhidyyatseziya. Ch. 1. Budslawski, Vilyeyski i Minski dekanaty, tekst i fota A. Yaromyenki, uvodziny U. Tratsewskaha, Minsk 2003 [Каталіџкія святыні. Мінска-магілёуская архідыяиэзія. Ч. 1. Будслаўскі, Вілейскі і Мінскі дэканаты, тэкст і фота А. Яроменкі, уводзіны У. Трацэўскага, Мінск 2003].

Kavalyenya A. A., Danilovich V. V., Mazyets V. H., Tratstsyak S. A., Byelaruskaya Narodnaya Respublika - krok da nyezalyezhnastsi. Da 100-hoddzya abvyashchennya. Histarychny narys, Minsk 2018 [Каваленя А. А., Даніловіч В. В., Мазец В. Г., Траццяк С. А., Беларуская Народная Рэспубліка - крок да незалежнасиі. Да 100-годдзя абвяшчэння. Гістарычны нарыс, Мінск 2018].

Korbut V. A., Ad Minska da Vil'ni. Historyya Byelarusi $w$ zhurnalistskikh natatkakh, Minsk 2016 [Корбут В. А., Ад Мінска да Вільні. Гісторыя Беларусі у журналісикіх нататках, Мінск 2016].

Korbut V. A., Las'ko D. M., Minsk. Spadchyna staroha horada. 1067-1917, Minsk 2016 [Корбут В. А., Ласько Д. М., Мінск. Спадчына старога горада. 1067-1917, Мінск 2016].

Korzan T., Minsk u syaredzinye XIX st. Z ulasnykh uspaminaw, pyer. V. Makarevich, «Arche» 2010, № 3 [Корзан Т., Мінск у сярэдзіне XIX cm. 3 уласных успамінаў, пер. В. Макарэвіч, «Аrche» 2010, № 3]. 
Віктар Корбут, Ідэнтычнасць жыхароў Мінска ў XIX - пачатку XX ст... 165

Korzon T., Mój pamiętnik przedhistoryczny, Kraków 1912.

Kowalewska Z., Obrazki mińskie. 1850-1863, Wilno 1912.

Kupala Ya., Powny zbor tvoraw. U 9 t. T. 9. Kn. 2. Dapawnyenni da papyarednikh tamow, Minsk 2003 [Купала Я., Поўны збор твораў. У 9 т. Т. 9. Кн. 2. Дапаўненні да папярэдніх тамоў, Мінск 2003].

Minsk i minchanye: dzyesyats' stahoddzyaw historyi. Krynitsy pa historyi horada. Satsyyal'nyya struktury i pawsyadzyonnasts'(da 945-hoddzya Minska): zbornik navukovykh artykulaw, uklad. A. I. Hrusha; redkal.: A. A. Kavalyenya i insh., Minsk 2012 [Мінск і мінчане: дзесяць стагоддзяў гісторыі. Крыніиы па гісторыі горада. Сацьяяльныя структуры і паўсядзённасиь (да 945-годдзя Мінска): зборнік навуковых артыкулаў, уклад. А. І. Груша; рэдкал.: А. А. Каваленя і інш., Мінск 2012].

Minsk u apisanni Uladzislava Syrakomli [u:] Pamyats': historyka-dakumyental'naya khronika Minska. U 4 kn. Kn. 1, Minsk 2001 [Мінск у апісанні Уладзіслава Сыракомлі [у:] Памящь: гісторыка-дакументальная хроніка Мінска. У 4 кн. Кн. 1, Мінск 2001].

Mińsk, «Tygodnik Wileński»1911, nr 13, 27 marca (9 kwietnia).

„Nasza Dola” 1906, nr 1, 2, 3, 5.

«Naša Dolâ» 1906, № 1, 2, 3, 6 [«Наша Доля» 1906, № 1, 2, 3, 6].

„Nasza Niwa” 1906, nr 1, 2, 4.

Nasze Kościoły. Djecezja Mińska. T. 2. Zesz. 11, red. J. Żyskar, Warszawa 1913.

Nasze Kościoły. Djecezja Mińska. T. 2. Zesz. 9, red. J. Żyskar, Warszawa 1913.

o-K-o, Mińsk. Dwa światy, «Tygodnik Wileński» 1911, nr 13, 27 marca (9 kwietnia).

Opisanie obchodu żałobnego nabożeństwa za duszę ś. p. Tadeusza Kościuszki, odbytego w Mińsku dnia 7. Marca 1818. roku w kościele Katedralnym, Wilno 1818.

Radzik R., Między zbiorowościa etniczna a wspólnota narodowa. Białorusini na tle przemian narodowych w Europie Środkowo-Wschodniej XIX st., Lublin 2000.

Rossiya. Polnoye geograficheskoye opisanie nashego otechestva: nastol'naya i dorozhnaya kniga dlya russkikh" lyudey, red. V. P. Semenov, obshch. ruk. P. P. Semenova i V. I. Lamanskogo. T. IX. Verkhneye Podnroprov'ye i Brolorussiya, sost. V. P. Semenov", M. V. Dovnar"'Zapol'skiy, D. Z.Shendrik", A. K.Kabanov", A. P. Sapunov", S.-Peterburg" 1905 [Россія. Полное географическое описаніе нашего отечества: настольная и дорожная книга для русскихъ людей, ред. В. П. Семеновъ, общ. рук. П. П. Семенова и В. И. Ламанского. T. IX. Верхнее Поднъпровье и Бълоруссія, сост. В. П. Семеновъ, М. В. Довнаръ-Запольскій, Д. З. Шендрикъ, А. К. Кабановъ, А. П. Сапуновъ, С.-Петербургъ 1905]. 
Ruszczyc F., Dziennik. Cz. 2. W Wilnie. 1919-1932, wybór, układ, oprac., wstęp i posłowie E. Ruszczyc, Warszawa 1996.

Shibeko Z. V., Minsk. Stranitsy zhizni dorevolyutsionnogo goroda, Minsk 1990 [Шибеко 3. В., Минск. Странищьы жизни дореволючиионного города, Минск 1990].

Staliūnas D., Rusinimas: Lietuva ir Baltarusija po 1863 m., Vilnius 2009.

Tarasiuk D., Między nadzieją a niepokojem. Działalność społeczno-kulturalna i polityczna Polaków na wschodniej Białorusi w latach 1905-1918, Lublin 2007.

Ts'vikyevich A., "Zapadno-russizm». Narysy z hramadzkay mys'li na Byelarusi w XIX i pachatku XX v., Minsk 1993 [Цьвікевіч А., «Западно-руссизм». Нарысы з грамадзкай мысьлі на Беларусі у ХІХ і пачатку ХХ в., Мінск 1993].

Ulashchyk M., Dats' narodu historyyu. Uspaminy, listy, ukl. A. Kawka, M. Skobla; navuk.-red.rada: V. Holubyew [i insh.], Minsk 2016 [Улашчык М., Дацьь народу гісторыю. Успаміны, лісты, укл. А. Каўка, М. Скобла; навук.-рэд. рада: В. Голубеў [і інш.], Мінск 2016].

Ulashchyk M., Myemuary i dzyonniki yak krynitsy pa historyi Byelarusi [u:] Ulashchyk M., Zbor tvoraw. T. 1. Pratsy pa arkhyeahrafii i krynitsaznawstvu, red. D. Vits'ko, D. Stolyar, M. Hal'pyarovich, ahul'n. red. D. Vits'ko, Smolyensk 2017 [M. Улашчык, Мемуары і дзённікі як крыніцы па гісторыі Беларусі, [w:] Idem, Збор твораў, т. 1: Працы па археаграфіі і крыніцазнаўству, рэд. Д. Віцько, Д. Столяр, М. Гальпяровіч, агульн. рэд. Д. Віцько, Смоленск 2017].

«Vybirajmasâ upročki»! «Skarèj u Tomsk"»!! Ab" toâ dobra razvědaǔ i raztlumačyǔ narodu A. İ., Picârburh": Sklad" glaǔny u knižnicy B. Adamoviča, u MěnskuLitoǔskam",1896 [«Выбираймася у прочки»! «Скарэй у Томскъ»!! Абъ тоя добра развьдаў и разтлумачыў народу А. І., Пицярбурхъ: Складъ глаўны у книжницы Б. Адамовича, у Мънску-Литоўскамъ, 1896].

Zienkiewicz T., Polskie życie literackie w Mińsku na poczatku XX w. (do r. 1921), Olsztyn 1997.

\section{Identity of the inhabitants of Minsk in the 19th and early 20th centuries in the light of memoirs}

The memories of the inhabitants of Minsk are a very valuable source for understanding the history of the city. Their special value is that they show the life of the city from the inside, with all its contradictions. Residents of Minsk, who considered themselves Poles, constituted a very significant part of its inhabitants until 1863, influenced the life of the city, they maintained these positions, although to a lesser extent, and later - until 1917. In the 19th and early 20th centuries, despite to be part of the Russian Empire, 
Віктар Корбут, Ідэнтычнасць жыхароў Мінска ў XIX - пачатку XX ст...

Minsk, as in the previous period, when it was part of the Grand Duchy of Lithuania and the Polish-Lithuanian Commonwealth, was part of the Polish-speaking cultural, mental space. Among the inhabitants of the city, mainly the Catholic faith, but also the Greek Catholic (after 1839 - among part of the Orthodox, former Uniates), gentry and philistines, the language of culture and daily communication was Polish, but at the same time there was an attachment to the traditions of the former Polish-Lithuanian Commonwealth. At the same time, Minsk, or Minsk Lithuanian, was understood as a city in Lithuania - i.e. on the territory of the former Grand Duchy of Lithuania, part of the former Polish-Lithuanian Commonwealth. In this article, based on the memoirs of the then residents and guests of the city - Tadeusz Korzon, Zofia Kowalewska, Ferdynand Szabłowski, Ferdynand Ruszczyc, Jan Bułhak, Adam Bahdanovič, Anielia Bahdanovič, Mikalaj Ulaščyk and etc. - an attempt was made to reflect their perception of Minsk and the place of the city in the then Lithuania and Byelorussia, Poland and Russia.

Key wo rds: Minsk, memoirs, Poles, Belarusians, Jews, Russians, January Uprising 
